\title{
The Full Bibliography of Dietrich Hoffmann
}

\author{
by \\ Barbara Boenke \\ Beiträge zur Tabakforschung International, Chausseestraße 51A, 10015 Berlin, Germany
}

The chronology of lifetime publications authored or coauthored by Dr Dietrich Hoffmann covers a broad spectrum of different aspects of chemical carcinogenesis, the effects of air pollution and diet on cancer and - last but not least - all areas of tobacco research. In addition, Dr Dietrich Hoffmann has served as editor of several monographs concerned with research in the fields mentioned above.

The important contributions of Dietrich Hoffmann to the science of carcinogenicity caused by lifestyle and environmental factors are impressively documented in the following list of his publications. It is based on entries in the scientific archive of Dr Hoffmann, which were kindly made available to the editors of this journal by Mrs Ilse Hoffmann. The material was reviewed and expanded by Dr Barbara Boenke of the Editorial Office of "Beiträge zur Tabakforschung International". [Beitr. Tabakforsch. Int. 24 (2011) 293-313].

1. Hoffmann, D. and E.L. Wynder: Identification of polynuclear aromatic hydrocarbons; $136^{\text {th }}$ National Meeting of the American Chemical Society (Am. Chem. Soc.), Atlantic City, NJ, 1959, No. 16U.

2. Wynder, E.L. and D. Hoffmann: A Study of Tobacco Carcinogenesis. VII. The role of higher polycyclic hydrocarbons; Cancer 12 (1959) 1079-1086.

3. Wynder, E.L. and D. Hoffmann: The carcinogenicity of benzofluoranthenes; Cancer 12 (1959) 1194-1199.

4. Hoffmann, D. and E.L. Wynder: On the isolation and identification of polycyclic aromatic hydrocarbons; Cancer 13 (1960) 1062-1073.

5. Hoffmann, D. and E.L. Wynder: Short-term determination of carcinogenic aromatic hydrocarbons; Anal. Chem. 32 (1960) 295.

6. Wynder, E.L. and D. Hoffmann: Studies in tobacco carcinogenesis; Proc. American Association for Cancer Research (Am. Assoc. Cancer Res.), 3 (1960) 164.

7. Wynder, E.L. and D. Hoffmann: Some practical aspects of the smoking-cancer problem; New Engl. J. Med. 262 (1960) 540-545.

8. Wynder, E.L. and D. Hoffmann: Tobacco smoking as a cause of cancer; in: Cancer Progress; edited by R.W. Raven, Butter- worths, London, UK, 1960, pp. 77-80.

9. Biekert, E., D. Hoffmann, and L. Enslein: Über 1.4-Oxazine. IV. Kondensation von 1.2-Amino-alkoholen mit $\alpha$ Ketocarbonsäure-estern zu 5.6-Dihydro-1.4-oxazinonen-(2); Chem. Ber. 94 (1961) 2778-2785.

10. Biekert, E., D. Hoffmann, and F.J. Meyer: Über 1.4-Oxazine. I. Darstellung kondensierter 1.4-Oxazinone-(2) durch Umsetzung von $o$-Aminophenolen mit $\alpha$-Ketoestern; Chem. Ber. 94 (1961) 1664-1675.

11. Biekert, E., D. Hoffmann, and F.J. Meyer: Über 1.4-Oxazine. II. Überführung der 1.4-Benzoxazinone-(2) in Phenmorpholone-(2) und $\mathrm{N}$-substituierte Aminoalkohole; Chem. Ber. 94 (1961) 1676-1682.

12. Hoffmann, D. and E.L. Wynder: Die quantitative Bestimmung von Phenolen im Tabakrauch; Beitr. Tabakforsch. 1 (1961) 101-106.

13. Wynder, E.L. and D. Hoffmann: Biological and chemical studies of tobacco smoke condensate; Proc. Am. Assoc. Cancer Res. 3 (1961) 280.

14. Wynder, E.L. and D. Hoffmann: Carcinogenicity of dibenzo(a,1)pyrene; Nature 192 (1961) 1092-1093.

15. Wynder, E.L. and D. Hoffmann: Present status of laboratory studies on tobacco carcinogenesis; Acta Pathol. Microbiol. Scand. 52 (1961) 119-132.

16. Wynder, E.L. and D. Hoffmann: A Study of Tobacco Carcinogenesis. VIII. The role of the acidic fractions as promoters; Cancer 14 (1961) 1306-1315.

17. Hoffmann, D. and E.L.Wynder: Analytical and biological studies on gasoline engine exhaust; National Cancer Institute (NCI) Monogr. 9 (1962) 91-116.

18. Hoffmann, D. and E.L. Wynder: A Study of Air Pollution Carcinogenesis. II. The isolation and identification of polynuclear aromatic hydrocarbons from gasoline engine exhaust condensate; Cancer 15 (1962) 93-102.

19. Wynder, E.L. and D. Hoffmann: A Study of Air Pollution Carcinogenesis. III. Carcinogenic activity of gasoline engine exhaust condensate; Cancer 15 (1962) 103-108.

20. Wynder, E.L. and D. Hoffmann: Air pollution and lung cancer; Proc. Natl. Conf. on Air Pollution, US Public Health Service Publ. No. 1022, 1962, pp. 143-148.

21. Wynder, E.L. and D. Hoffmann: Studies with gaseous and particulate phase of tobacco smoke; $53^{\text {rd }}$ Ann. Meeting Am. Assoc. Cancer Res., 1962, pp. 373.

22. Wynder, E.L. and D. Hoffmann: The role of skin neoplasia in tobacco carcinogenesis; in: Tobacco and Health; edited by G. 
G. James and R. Rosenthal, Thomas, Springfield, IL, 1962, pp. 61-71.

23. Hoffmann, D., G. Rathkamp, and E.L. Wynder: Comparison of the yields of several selected components in the smoke from different tobacco products; J. Natl. Cancer Inst. 31 (1963) 627-637.

24. Hoffmann, D. and E.L. Wynder: Filtration of phenols from cigarette smoke; J. Natl. Cancer Inst. 30 (1963) 67-84.

25. Hoffmann, D. and E.L. Wynder: Die Filtration von Phenolen aus Cigarettenrauch; Beitr. Tabakforsch. 2 (1963) 51-66.

26. Hoffmann, D. and E.L. Wynder: Studies on Gasoline Engine Exhaust; J. Air Pollut. Control Assoc. 13 (1963) 322-327.

27. Wynder, E.L. and D. Hoffmann: Bioassays on the carcinogenicity of tobacco smoke condensate and air pollutants; Proc. Am. Assoc. Cancer Res. 4 (1963) 73.

28. Wynder, E.L. and D. Hoffmann: Experimental aspects of tobacco carcinogenesis; Dis. Chest 44 (1963) 337-344.

29. Wynder, E.L. and D. Hoffmann: Ein experimenteller Beitrag zur Tabakrauchkanzerogenese [An experimental contribution to the problem of tobacco smoke carcinogenesis]; Dtsch. Med. Wochenschr. 88 (1963) 623-628.

30. Wynder, E.L., H.E. Kaiser, D.A. Goodman, and D. Hoffmann: A method for determining ciliastatic components in cigarette smoke; Cancer 16 (1963) 1222-1225.

31. Hoffmann, D., G. Rathkamp, and E.L. Wynder: Vergleich der Ausbeute an mehreren ausgewählten Komponenten im Rauch verschiedener Tabakerzeugnisse; Beitr. Tabakforsch. 2 (1964) $123-130$

32. Wynder, E.L. and D. Hoffmann: Experimental tobacco carcinogenesis; Adv. Cancer Res. 8 (1964) 249-453.

33. Hoffmann, D., E. Theisz, and E.L. Wynder: Studies on the carcinogenicity of gasoline exhaust; J. Air Pollut. Control Assoc. 15 (1965) 162-165.

34. Wynder, E.L., D.A. Goodman, and D. Hoffmann: Ciliatoxic Components in Cigarette Smoke. II. Carboxylic acids and aldehydes; Cancer 18 (1965) 505-509.

35. Wynder, E.L., D.A. Goodman, and D. Hoffmann: Ciliatoxic Components in Cigarette Smoke. III. In vitro comparison of different smoke components; Cancer 18 (1965) 1652-1658.

36. Wynder, E.L. and D. Hoffmann: Reduction of tumorigenicity of cigarette smoke; JAMA 192 (1965) 88-94.

37. Wynder, E.L. and D. Hoffmann: Some laboratory and epidemiological aspects of air pollution carcinogenesis; J. Air Pollut. Control Assoc. 15 (1965) 155-159.

38. Wynder, E.L., D. Hoffmann, and O. Auerbach: The role of particulate and volatile components in tobacco carcinogenesis; Proc. Am. Assoc. Cancer Res. 6 (1965) 69.

39. Hoffmann, D. and J. Rubin: Chemical Studies on Tobacco Smoke. I. the Quantitative Determination of Indoles in Cigarette Smoke; Beitr. Tabakforsch. 3 (1966) 409-414.

40. Hoffmann, D. and E.L. Wynder: The tumor initiators in tobacco smoke; Proc. Am. Assoc. Cancer Res. 7 (1966) 32.

41. Hoffmann, D. and E.L. Wynder: Beitrag zur carzinogenen Wirkung von Dibenzopyrenen; Z. Krebsforsch. 68 (1966) 137-149.

42. Rathkamp, G., D. Hoffmann, and E.L. Wynder: Experiments on the reduction of polynuclear aromatic hydrocarbons in cigarette smoke; presented at the $20^{\text {th }}$ Tobacco Chemists' Research Conference (TCRC), Winston-Salem, NC, 1966, No. 19.

43. Woziwodzki, H. and D. Hoffmann: Free higher fatty acids in tobacco and tobacco smoke; presented at the $20^{\text {th }}$ TCRC, Winston-Salem, NC, 1966, No. 16.

44. Wynder, E.L. and D. Hoffmann: Beziehungen zwischen Epidemiologie und experimenteller Karzinogenese; Münch. Med. Wochenschr. 108 (1966) 1501-1512.

45. Wynder, E.L. and D. Hoffmann: Current concepts of environmental cancer research; Med. Clin. North Am. 50 (1966) 631-650.
46. Hoffmann, D., G. Rathkamp, and J. Rubin: Chemical Studies on Tobacco Smoke. II. Comparison of the yields of several selected components in the smoke from five major Turkish tobacco varieties; Food Cosmet. Toxicol. 5 (1967) 37-38.

47. Hoffmann, D. and E.L. Wynder: The reduction of the tumorigenicity of cigarette smoke condensate by addition of sodium nitrate to tobacco; Cancer Res. 27 (1967) 172-174.

48. Rathkamp, G., D. Hoffmann, and E.L. Wynder: Primary and secondary nitrohydrocarbons in cigarette smoke; presented at the $21^{\text {st }}$ TCRC, Durham, NC, 1967, No. 25.

49. Wynder, E.L. and D. Hoffmann: Nutrition and Cancer; in: Prevention of Cancer; edited by R.W. Raven and F.J.C. Roe, Butterworths, London, England, 1967, pp. 11-18.

50. Wynder, E.L. and D. Hoffmann: Tobacco and Tobacco Smoke. Studies in Experimental Carcinogenesis; Academic Press, New York, NY, 1967.

51. Hoffmann, D. and G. Rathkamp:. Chemical Studies on Tobacco Smoke. III. Primary and Secondary Nitroalkanes in Cigarette Smoke; Beitr. Tabakforsch. 4 (1968) 124-134.

52. Hoffmann, D. and G. Rathkamp: Chemical Studies on Tobacco Smoke. V. Quantitative Determination of Chlorinated Hydrocarbon Insecticides in Cigarette Tobacco and its Smoke; Beitr. Tabakforsch. 4 (1968) 201-214.

53. Hoffmann, D., G. Rathkamp, and H. Woziwodzki: Chemical Studies on Tobacco Smoke. VI. The Determination of Carbazoles in Cigarette Smoke; Beitr. Tabakforsch. 4 (1968) 253-263.

54. Hoffmann, D. and H. Woziwodzki: Chemical Studies on Tobacco Smoke. IV. The Quantitative Determination of Free Nonvolatile Fatty Acids in Tobacco and Tobacco Smoke; Beitr. Tabakforsch. 4 (1968) 167-175.

55. Hoffmann, D. and E.L. Wynder: Chemical Analysis and Carcinogenic Bioassays of Organic Particulate Pollutants, in: Air Pollution, Vol. II: Analysis, Monitoring and Surveying; edited by A.C. Stern, Academic Press, New York, NY, 1968, pp. $187-247$.

56. Hoffmann, D. and E.L. Wynder: Selective reduction of the tumorigenicity of tobacco smoke. Experimental approaches; NCI Monogr. 28 (1968) 151-172.

57. Masuda, Y., D. Hoffmann, and E.L. Wynder: $\alpha$-Naphthylamine and $\beta$-naphthylamine in cigarette smoke; presented at the $22^{\text {nd }}$ TCRC, Richmond, VA, 1968, No. 22.

58. Wynder, E.L. and D. Hoffmann: Experimental tobacco carcinogenesis; Science 162 (1968) 862-871.

59. Wynder, E.L. and D. Hoffmann: Tobacco and Tobacco Smoke; Nature 219 (1968) 661-662.

60. Wynder, E.L. and D. Hoffmann: Selected laboratory methods in tobacco carcinogenesis; in: Methods in Cancer Research, Vol. 4; edited by E.H. Busch, Academic Press, New York, NY, 1968, pp. 3-52.

61. Wynder, E.L. and D. Hoffmann (Editors): Toward a less harmful cigarette; NCI Monograph 28, American Cancer Society, Bethesda, MD, 1968.

62. Wynder, E.L., K.T. Taguchi, V. Baden, and D. Hoffmann: A Study of Tobacco Carcinogenesis. IX. The effect of cigarette smoke on the respiratory tract of mice after passive inhalation; Cancer 21 (1968) 134-153.

63. Hoffmann, D., Y. Masuda, and E.L. Wynder: $\alpha$-Naphthylamine and $\beta$-naphthylamine in cigarette smoke; Nature 221 (1969) 254-256.

64. Hoffmann, D., G. Rathkamp, and S. Nesnow: [Chemical Studies on Tobacco Smoke. VIII.] Quantitative determination of 9-methylcarbazoles in cigarette smoke; Anal. Chem. 41 (1969) 1256-1259.

65. Hoffmann, D., G. Rathkamp, and E.L. Wynder: Chemical Studies on Tobacco Smoke. IX. Quantitative Analysis of Chlorinated Hydrocarbon Insecticides; Beitr. Tabakforsch. 5 (1969) 140-148.

66. Masuda, Y. and D. Hoffmann: [Chemical Studies on Tobacco 
Smoke. VII.] Quantitative determination of 1-naphthylamine and 2-naphthylamine in cigarette smoke; Anal. Chem. 41 (1969) 650-652.

67. Masuda, Y. and D. Hoffmann: A method for the determination of primary amines of polynuclear aromatic hydrocarbons; J. Chromatogr. Sci. 7 (1969) 694-697.

68. Mazzola, V., G. Rathkamp, and D. Hoffmann: N-Alkylindoles, $N$-alkylcarbazoles, and Dibenzofurans in Cigarette Smoke; presented at the $23^{\text {rd }}$ TCRC, Philadelphia, PA, 1969 , No. 22.

69. Radford, E.P., V.R. Hunt, J.B. Little, E.L. Wynder, and D. Hoffmann: Carcinogenicity of Tobacco-smoke Constituents; Science 165 (1969) 312-313.

70. Rathkamp, G. and D. Hoffmann: The inhibition of the pyrosynthesis of several selective smoke components. Experimental findings and theoretical considerations; presented at the $23^{\text {rd }}$ TCRC, Philadelphia, PA, 1969, No. 29.

71. Wynder, E.L. and D. Hoffmann: Current studies on etiology and prevention; in: Lung Cancer: a study of 5,000 Memorial Hospital cases; edited by E.L. Watson, Mosby Company, St. Louis, MO, 1969, pp. 15-34

72. Wynder, E.L. and D. Hoffmann: A Study of Tobacco Carcinogenesis. X. Tumor promoting activity; Cancer 24 (1969) 289-301.

73. Wynder, E.L. and D. Hoffmann: Bioassays in tobacco carcinogenesis; Prog. Exp. Tumor Res. 11 (1969) 163-193.

74. Hoffmann, D. and V. Mazzola: Chemical Studies on Tobacco Smoke. XI. Dibenzofurans in Cigarette Smoke; Beitr. Tabakforsch. 5 (1970) 183-188.

75. Hoffmann, D. and G. Rathkamp: [Chemical Studies on Tobacco Smoke. X.] Quantitative determination of 1-alkylindoles in cigarette smoke; Anal. Chem. 42 (1970) 366-370.

76. Hoffmann, D. and G. Rathkamp: Chemical Studies on Tobacco Smoke. XII. Quantitative determination of nitrobenzenes in cigarette smoke; Anal. Chem. 42 (1970) 1643-1647.

77. Hoffmann, D. and E.L. Wynder: Chamber development and aerosol dispersion; in: Inhalation Carcinogenesis; edited by H.G. Hanna et al., US Atomic Energy Symp. Ser. 18, Washington, DC, 1970, pp. 173-191.

78. Rathkamp, G. and D. Hoffmann: Fluorenes and fluoranthenes in cigarette smoke; presented at the $24^{\text {th }}$ TCRC, Montreal, Canada, 1970, No. 28.

79. Rathkamp, G. and D. Hoffmann: Chemical Studies on Tobacco Smoke. XIII. Inhibition of the Pyrosyntheses of Several Selective Smoke Constituents; Beitr. Tabakforsch. 5 (1970) 302-306.

80. Wynder, E.L. and D. Hoffmann: the Epidermis and the Respiratory Tract as Bioassay Systems in Tobacco Carcinogenesis; Brit. J. Cancer 24 (1970) 574-587.

81. Hoffmann, D. and J. Vais: Analysis of volatile $N$-nitrosamines in unaged mainstream smoke of cigarettes; presented at the $25^{\text {th }}$ TCRC, Louisville, KY, 1971, No. 23.

82. Hoffmann, D. and E.L. Wynder: A Study of Tobacco Carcinogenesis. XI. Tumor initiators, tumor accelerators, and tumor promoting activity of condensate fractions; Cancer 27 (1971) 848-864.

83. Marquardt, H., A. Bendich, F.S. Phillips, and D. Hoffmann: Binding of [G-3H]-7,12-dimethylbenz $(a)$ anthracene to DNA of normal and of rapidly dividing hepatic cells of rats; Chem. Biol. Interactions 3 (1971) 1-11.

84. Rathkamp, G., T.C. Tso, and D. Hoffmann: On the correlation between various leaf constituents and selected smoke compounds; presented at the $25^{\text {th }}$ TCRC, Louisville, KY, 1971, No. 6.

85. Singer, G. and D. Hoffmann: 4- $N$-Alkylaminophenols in cigarette smoke; presented at the $25^{\text {th }} \mathrm{TCRC}$, Louisville, KY, 1971, No. 22.

86. Wynder, E.L. and D. Hoffmann: Carcinogens in the air; Proc. $24^{\text {th }}$ Ann. Symp. on Fundamental Cancer Research, Houston,
TX, Williams \& Wilkens, Baltimore, MD, 1971, pp.118-141.

87. Wynder, E.L., D. Hoffmann, P. Ashwanden, and R. Wachsmuth (Eds.): Less harmful ways of smoking; Proc. of a Workshop of the $2^{\text {nd }}$ World Conf. on Smoking and Health, London, UK, 1971.

88. Brunnemann, K.D. and D. Hoffmann: On the $\mathrm{pH}$ of tobacco smoke; presented at the Joint Conference CORESTA and $26^{\text {th }}$ TCRC, Williamsburg, VA, 1972, No. 11.

89. Hoffmann, D.: Benzo[a]pyrene in polluted air; Prev. Med. 1 (1972) 450-451.

90. Hoffmann, D. and G. Rathkamp: [Chemical Studies on Tobacco Smoke. XIV.] Quantitative determination of fluorenes in cigarette smoke and their formation by pyrosynthesis; Anal. Chem. 44 (1972) 899-904.

91. Hoffmann, D., G. Rathkamp, S. Nesnow, and E.L. Wynder: [Chemical Studies on Tobacco Smoke. XVI.] Fluoranthenes: Quantitative determination in cigarette smoke, formation by pyrolysis, and tumor initiating activity; J. Natl. Cancer Inst. 49 (1972) 1165-1175.

92. Hoffmann, D. and E.L. Wynder: Chemical Studies on Tobacco Smoke. XV. Chemical Composition and Tumorigenicity of Tobacco Smoke; in: The Chemistry of Tobacco and Tobacco Smoke; edited by I. Schmeltz, Plenum Press, New York, NY, 1972, pp. 123-147.

93. Hoffmann, D. and E.L. Wynder: [Chemical Studies on Tobacco Smoke. XVIII.] Smoke of cigarettes and little cigars: An analytical comparison; Science 178 (1972) 1197-1199.

94. Hoffmann, D. and E.L. Wynder: Respiratory Carcinogens: Their Nature and Precursors; in: Identification and measurement of environmental pollutants: proceedings of a symposium; edited by B. Westley, Campbell Printing, Ottawa, Canada, 1972, pp. 9-16.

95. Hoffmann, D. and E.L. Wynder: Selective Reduction of the Tumorigenicity of Tobacco Smoke. II. Experimental approaches; J. Natl. Cancer Inst. 48 (1972) 1855-1868.

96. Rathkamp, G. and D. Hoffmann: Polynuclear aromatic hydrocarbon profile of tobacco smoke; presented at the Joint Conference CORESTA and $26^{\text {th }}$ TCRC, Williamsburg, VA, 1972, No. 09.

97. Wynder, E.L. and D. Hoffmann: Less harmful ways of smoking; J. Natl. Cancer Inst. 48 (1972) 1749-1758.

98. Brunnemann, K.D., D. Hoffmann, and E.L. Wynder: Studies on the inhalability of cigarette and cigar smoke; presented at the $27^{\text {th }}$ TCRC, Winston-Salem, NC, 1973, No. 27.

99. Hecht, S.S., W.E. Bondinell, and D. Hoffmann: Isolation and identification of alkylchrysenes in cigarette smoke; presented at the $27^{\text {th }}$ TCRC, Winston-Salem, NC, 1973, No. 32.

100. Hoffmann, D., G. Rathkamp, K.D. Brunnemann, and E.L. Wynder: [Chemical Studies on Tobacco Smoke. XXII.] On the profile analysis of tobacco smoke. Sci. Total Environ. 2 (1973) 157-171.

101. Liu, Y.Y. and D. Hoffmann: Maleic hydrazide and volatile hydrazines in cigarette smoke; presented at the $27^{\text {th }}$ TCRC, Winston-Salem, NC, 1973, No. 29.

102. Liu, Y.Y. and D. Hoffmann: Chemical Studies on Tobacco Smoke. XIX. Quantitative chromatographic determination of maleic hydrazide in cigarette smoke; Anal. Chem. 45 (1973) 2270-2273.

103. Rathkamp, D., D.K. Chao, and D. Hoffmann: Analytical studies on nonvolatile $N$-nitrosamines in cigarette smoke; presented at the $27^{\text {th }}$ TCRC, Winston-Salem, NC, 1973, No. 26.

104. Rathkamp, G., T.C. Tso, and D. Hoffmann: Chemical Studies on Tobacco Smoke. XX. Smoke Analysis of Cigarettes Made from Bright Tobaccos Differing in Variety and Stalk Positions; Beitr. Tabakforsch. 7 (1973) 179-189.

105. Schmeltz, I. and D. Hoffmann: Formation of polynuclear 
aromatic hydrocarbons from combustion of organic matter; in: Carcinogenesis. Polynuclear aromatic hydrocarbons: Chemistry, metabolism, and carcinogenesis; edited by R.I. Freudenthal and P.I. Jones, Raven Press, New York, NY (1973) 225-239.

106. Tso, T.C., G. Rathkamp, and D. Hoffmann: Chemical Studies on Tobacco Smoke. XXI. Correlation and Multiple Regression among Selected Cigarette-smoke Constituents and Leaf Characteristics of Bright Tobacco; Beitr. Tabakforsch. 7 (1973) 190-194.

107. Brunnemann, K.D. and D. Hoffmann: Gas chromatographic determination of ammonia in cigarette and cigar smoke; presented at the $28^{\text {th }}$ TCRC, Raleigh, NC, 1974, No. 53.

108. Brunnemann, K.D. and D. Hoffmann: Chemical Studies on Tobacco Smoke. XXIV. A quantitative method for carbon monoxide and carbon dioxide in cigarette and cigar smoke; J. Chromatogr. Sci. 12 (1974) 70-75.

109. Brunnemann, K.D. and D. Hoffmann: [Chemical Studies on Tobacco Smoke. XXV.] The pH of tobacco smoke; Food Cosmet. Toxicol. 12 (1974) 115-124.

110. Hecht, S.S., E.W. Bondinell, and D. Hoffmann: Chemical Studies on Tobacco Smoke. XXIX. Chrysene and methylchrysenes: Presence in tobacco and carcinogenicity; J. Natl. Cancer Inst. 53 (1974) 1121-1133.

111. Hecht, S.S., R.M. Ornaf, and D. Hoffmann: $N$-nitrosoalkaloids in tobacco; presented at the $28^{\text {th }}$ TCRC, Raleigh, NC, 1974, No. 36

112. Hecht, S.S., R.L. Thorne, and D. Hoffmann: Studies of tumor promoters in tobacco smoke; presented at the $28^{\text {th }}$ TCRC, Raleigh, NC, 1974, No. 42.

113. Hoffmann, D., W.E. Bondinell, and E.L. Wynder: Carcinogenicity of methylchrysenes; Science 183 (1974) 215-216.

114. Hoffmann, D., S.S. Hecht, and R.M. Ornaf: Nonvolatile Nnitrosamines in tobacco and tobacco smoke; presented at the CORESTA Symposium Montreux, Suisse, 1974, No. 36.

115. Hoffmann, D., S.S. Hecht, R.M. Ornaf, and E.L. Wynder: [Chemical Studies on Tobacco Smoke. XXX.] N'Nitrosonornicotine in tobacco; Science 186(1974) 265-267.

116. Hoffmann, D., G. Rathkamp, and Y.Y. Liu: Chemical Studies on Tobacco Smoke. XXVI. On the isolation and identification of volatile and non-volatile $N$-nitrosamines and hydrazines in cigarette smoke; in: $N$-Nitroso Compounds in the Environment, IARC Sci. Publ. 9 (1974) 159-165.

117. Hoffmann, D., L.D. Sanghvi, and E.L. Wynder: [Chemical Studies on Tobacco Smoke. XXVIII.] Comparative chemical analysis of Indian bidi and American cigarette smoke; Int. J. Cancer 14 (1974) 49-53.

118. Hoffmann, D. and E.L. Wynder: Positive Controls in Environmental Respiratory Carcinogenesis; in: Carcinogenesis Testing of Chemicals; edited by L. Goldberg, CRC Press, Cleveland, OH, 1974, pp. 35-39.

119. Hu, M.W., W.E. Bondinell, and D. Hoffmann: Chemical Studies on Tobacco Smoke. XXIII. Synthesis of carbon-14 labelled myosmine, nornicotine, and $N$ '-nitrosonornicotine; J. Labelled Compd. 10 (1974) 79-88.

120. Kobayashi, N., D. Hoffmann, and E.L. Wynder: A Study of Tobacco Carcinogenesis. XII. Epithelial changes induced in the upper respiratory tracts of Syrian golden hamsters by cigarette smoke; J. Natl. Cancer Inst. 53 (1974) 1085-1089.

121. Liu, Y.Y., I. Schmeltz, and D. Hoffmann: Chemical studies on tobacco smoke [XXVII]. Quantitative analysis of hydrazine in tobacco and cigarette smoke; Anal. Chem. 46 (1974) 885-889.

122. Schmeltz, I., A. de Paolis, and D. Hoffmann: Quantitative analyses of major phytosterols in tobacco and tobacco smoke; presented at the $28^{\text {th }}$ TCRC, Raleigh, NC, 1974, No. 43.

123. Schmeltz, I., D. Hoffmann, and E.L. Wynder: [Chemical
Studies on Tobacco Smoke. XXXII.] Toxic and Tumorigenic Agents in Tobacco Smoke: Analytical Methods and Modes of Origin; Proceedings of the $8^{\text {th }}$ Ann. Conf. on Trace Substances in Environmental Health; edited by D.D. Hemphill, University of Missouri, Columbia, MO, 1974, pp. 281-295.

124. Wynder, E.L., K. Mabuchi, and D. Hoffmann: Tobacco; in: Cancer Epidemiology and Prevention; edited by $\mathrm{D}$. Schottenfeld, Charles C. Thomas Publ., Springfield, IL, 1974, pp. 102-125.

125. Brunnemann, K.D. and D. Hoffmann: Chemical Studies on Tobacco Smoke. XXXIV. Gas chromatographic determination of ammonia in cigarette and cigar smoke; J. Chromatogr. Sci. 13 (1975) 159-163.

126. Brunnemann, K.D., C.-H. Lee, and D. Hoffmann: A Study of the Precursors and on the Quantitative Analysis of Catechols in Cigarette Smoke; presented at the $29^{\text {th }}$ TCRC, College Park, MD, 1975, No. 46.

127. Hecht, S.S., M. Loy, R.R. Maronpot, and D. Hoffmann: A Study of Chemical Carcinogenesis: Comparative carcinogenicity of 5-methylchrysene, benzo $(a)$ pyrene and modified chrysenes. Cancer Lett., 1 (1975) 147-153.

128. Hecht, S.S., R.M. Ornaf, C.B. Chen, D. Hoffmann, and T.C. Tso; On the Origin of $N$-Nitrosonornicotine in Tobacco; presented at the $29^{\text {th }}$ TCRC, College Park, MD, 1975, No. 34.

129. Hecht, S.S., R.M. Ornaf, and D. Hoffmann: [Chemical Studies on Tobacco Smoke. XLI.] Determination of $N^{\prime}$ nitrosonornicotine in tobacco by high speed liquid chromatography; Anal. Chem. 47 (1975) 2046-2048.

130. Hecht, S.S., R.M. Ornaf, and D. Hoffmann: Chemical Studies on Tobacco Smoke. XXXIII. $N$ '-Nitrosonornicotine in tobacco: Analysis of possible contributing factors and biologic implications; J. Natl. Cancer Inst. 54 (1975) 1237-1244

131. Hecht, S.S., R.L. Thorne, R.R. Maronpot, and D. Hoffmann: A Study of Tobacco Carcinogenesis. XIII. Tumor promoting subfractions of the weakly acidic fraction; J. Natl. Cancer Inst. 55 (1975) 1329-1336.

132. Hoffmann, D., K.D. Brunnemann, G.B. Gori, and E.L. Wynder: On the carcinogenicity of marijuana smoke; Rec. Adv. Phytochem. 9 (1975) 63-81.

133. Hoffmann, D., S.S. Hecht, I. Schmeltz, K.D. Brunnemann, and E.L. Wynder: Chemical Studies on Tobacco Smoke. XLIV. New separation techniques for classes of smoke compounds; Rec. Adv. Tobacco Sci. 1 (1975) 97-122.

134. Hoffmann, D., C.P. Patrianakos, K.D. Brunnemann and G.B. Gori: On the Analysis of Vinyl Chloride in Tobacco Smoke; presented at the $29^{\text {th }}$ TCRC, College Park, MD, 1975, No. 17.

135. Hoffmann, D., R. Raineri, S.S. Hecht, R.R. Maronpot, and E.L. Wynder: A Study of Tobacco Carcinogenesis. XIV. Effect of $N$ '-nitrosonornicotine and $N^{\prime}$ '-nitrosoanabasine in rats; J. Natl. Cancer Inst. 55 (1975) 977-981.

136. Hoffmann, D. and E.L. Wynder: New Separation Techniques for Classes of Smoke Compounds; presented at the $29^{\text {th }}$ TCRC, College Park, MD, 1975, No. 5.

137. Hoffmann, D. and E.L. Wynder: Chemical Studies on Tobacco Smoke. XLIII. The active fractions of cigarette smoke in experimental tobacco carcinogenesis. A review; Tobacco Res. (India) 1 (1975) 88-97.

138. Schmeltz, I., K.D. Brunnemann, D. Hoffmann, and A. Cornell: On the chemistry of cigar smoke: comparisons between experimental little and large cigars; presented at the $29^{\text {th }}$ TCRC, College Park, MD, 1975, No. 41.

139. Schmeltz, I., A. de Paolis, and D. Hoffmann: [Chemical Studies on Tobacco Smoke. XXXI.] Phytosterols in Tobacco: Quantitative Analysis and Fate in Tobacco Combustion; Beitr. Tabakforsch. 8 (1975) 211-218.

140. Schmeltz, I., D. Hoffmann, and J. Tosk: Naphthalenes in Tobacco Smoke: Analysis and Formation; presented at the 
$29^{\text {th }}$ TCRC, College Park, MD, 1975, No. 22.

141. Schmeltz, I., D. Hoffmann, and E.L. Wynder: The influence of tobacco smoke on indoor atmospheres. I. An overview; Prev. Med. 4 (1975) 66-82.

142. Wynder, E.L. and D. Hoffmann: The tenth anniversary of the Surgeon General's report on smoking and health. Have we made any progress? Guest Editorial; J. Natl. Cancer Inst. 54 (1975) 533-534.

143. Wynder, E.L., D. Hoffmann, P. Chan, and B. Reddy: Interdisciplinary and Experimental Approaches: Metabolic Epidemiology; in: Persons at High Risk of Cancer. An Approach to Cancer Etiology and Control; edited by J.F. Fraumeni, Academic Press, New York, NY, 1975, pp. 485-501.

144. Brunnemann, K.D., S.S. Hecht, and D. Hoffmann: Analysis of $\mathrm{N}$-Nitrosamines in Tobacco and Tobacco Smoke with the Aid of the Thermal Energy Analyzer; presented at the $30^{\text {th }}$ TCRC, Nashville, TN, 1976, No. 38.

145. Brunnemann, K.D. and D. Hoffmann: Analysis of Polynuclear Aromatic Hydrocarbons in the Respiratory Environment; in: Carcinogenesis - A Comprehensive Survey; edited by R.I. Freudenthal and P.W. Jones, Raven Press, New York, NY, 1976, pp. 283-297.

146. Brunnemann, K.D., D. Hoffmann, E.L. Wynder, and G.B. Gori: Chemical Studies on Tobacco Smoke. XXXVII. Determination of tar, nicotine, and carbon monoxide in cigarette smoke. A comparison of international smoking conditions; in: Smoking and Health: I. Modifying the Risk for the Smoker. Proc. $3^{\text {rd }}$ World Conf. on Smoking and Health; edited by E.L. Wynder et al., US Gov. Print. Off., Washington, DC, 1976, pp. 441-449.

147. Brunnemann, K.D., H.C. Lee, and D. Hoffmann: Chemical Studies on Tobacco Smoke. XLVII. On the quantitative analysis of catechols and their reduction; Anal. Lett. 9 (1976) 939-955.

148. Brunnemann, K.D., L. Yu, and D. Hoffmann: Gas Chromatographic Determination of Hydrogen Cyanide and Cyanogen in Tobacco Smoke; presented at the $30^{\text {th }}$ TCRC, Nashville, TN, 1976, No. 36.

149. Hecht, S.S., C.B. Chen, and D. Hoffmann: Synthesis of $N$ nitrosamino aldehydes; Tetrahedron Lett. 8 (1976) 593-596.

150. Hecht, S.S., M. Loy, and D. Hoffmann: On the Structure and Carcinogenicity of the Methylchrysenes; in: Carcinogenesis - A Comprehensive Survey; edited by R.I. Freudenthal and P.W. Jones, Raven Press, New York, NY, 1976, pp. 325-340.

151. Hecht, S.S., R.M. Ornaf, M. Dong, and D. Hoffmann: Studies on Nonvolatile Nitrosamines in Tobacco; presented at the $30^{\text {th }}$ TCRC, Nashville, TN, 1976, No. 27.

152. Hecht, S.S., I. Schmeltz, D. Hoffmann, and E.L. Wynder: Chemical Studies on Tobacco Smoke. XL. Identification of carcinogens in tobacco; in: Smoking and Health: I. Modifying the Risk for the Smoker. Proc. 3rd World Conf. on Smoking and Health; edited by E.L. Wynder, et al., US Gov. Print. Off., Washington, DC, 1976, pp. 191-202.

153. Hecht, S.S., T.C. Tso, and D. Hoffmann: Selective Reduction of Tumorigenicity of Tobacco Smoke. IV. Approaches to the reduction of nitrosamines and aromatic amines; in: Smoking and Health: I. Modifying the Risk for the Smoker. Proc. $3^{\text {rd }}$ World Conf. on Smoking and Health; edited by E.L. Wynder et al., US Gov. Print. Off., Washington, DC, 1976, pp. 535-545.

154. Hoffmann, D., S.S. Hecht, K.D. Brunnemann, and E.L. Wynder: Analysis and formation of $N$-nitrosamines in tobacco and tobacco smoke; presented at the CORESTA Congress Tokyo, Japan, 1976, No. S017.

155. Hoffmann, D., S.S. Hecht, R.M. Ornaf, E.L. Wynder, and T.C. Tso: Chemical Studies on Tobacco Smoke. XLII. Nitrosonornicotine: Presence in Tobacco, Formation and
Carcinogenicity; in: Asbestos, IARC Monographs on the Evaluation of Carcinogenic Risks to Humans, No. 14, 1976, pp. 307-320.

156. Hoffmann, D., C.P. Patrianakos, K.D. Brunnemann, and G.B. Gori: Chemical Studies on Tobacco Smoke. XXXVI. Chromatographic determination of vinyl chloride in tobacco smoke; Anal. Chem. 48 (1976) 47-50.

157. Hoffmann, D., I. Schmeltz, S.S. Hecht, and E.L. Wynder: Chemical Studies on Tobacco Smoke. XXXIX. On the identification of carcinogens, tumor promoters, and cocarcinogens in tobacco smoke; in: Smoking and Health: I. Modifying the Risk for the Smoker. Proc. $3^{\text {rd }}$ World Conf. on Smoking and Health; edited by E.L. Wynder et al., US Gov. Print. Off., Washington, DC, 1976, pp. 125-145.

158. Hoffmann, D. and E.L. Wynder: Environmental Respiratory Carcinogenesis; in: Chemical Carcinogenesis; edited by C.E. Searle, Am. Chem. Soc. Monograph No. 173, Washington, DC, 1976, pp. 324-365.

159. Hoffmann, D. and E.L. Wynder: Selective reduction of tumorigenicity of tobacco smoke. III. The reduction of polynuclear aromatic hydrocarbons in cigarette smoke; in: Smoking and Health. I: Modifying the Risk for the Smoker. Proc. $3^{\text {rd }}$ World Conf. on Smoking and Health; edited by E.L. Wynder et al., US Gov. Print. Off., Washington, DC, 1976, pp. 495-504.

160. Hoffmann, D. and E.L. Wynder: Smoking and occupational cancers; Prev. Med. 5 (1976) 245-261.

161. Schmeltz, I., K.D. Brunnemann, D. Hoffmann, and A. Cornell: [Chemical Studies on Tobacco Smoke. XLV.] On the chemistry of cigar smoke: Comparisons Between Experimental Little and Large Cigars; Beitr. Tabakforsch. 8 (1976) 367-377.

162. Schmeltz, I. and D. Hoffmann: Chemical Studies on Tobacco Smoke. XXXVIII. The physicochemical nature of cigarette smoke; in: Smoking and Health: I. Modifying the Risk for the Smoker; Proc. $3^{\text {rd }}$ World Conf. on Smoking and Health; edited by E.L. Wynder et al., US Gov. Print. Off., Washington, DC, 1976, pp. 13-34.

163. Schmeltz, I. and D. Hoffmann: Formation of Polynuclear Aromatic Hydrocarbons from Combustion of Organic Matter; in: Carcinogenesis - Polynuclear Aromatic Hydrocarbons: Chemistry, Metabolism, and Carcinogenesis; edited by R.I. Freudenthal and P.W. Jones, Raven Press, New York, NY, 1976, pp. 225-239.

164. Schmeltz, I., J. Tosk, and D. Hoffmann: Chemical Studies on Tobacco Smoke. XLVI. Formation and determination of naphthalenes in cigarette smoke; Anal. Chem. 48 (1976) 645-650.

165. Schmeltz, I., J. Tosk, G. Jacobs, and D. Hoffmann: The Redox Potential and Quinone Content of Cigarette Smoke; presented at the $30^{\text {th }}$ TCRC, Nashville, TN, 1976, No. 44.

166. Schmeltz, I., A. Wenger, D. Hoffmann, and T.C. Tso: Use of Radioactive Tobacco Isolates for Studying the Formation of Selected Smoke Components; presented at the $30^{\text {th }}$ TCRC, Nashville, TN, 1976, No. 35.

167. Tso, T.C., G.B. Gori, and D. Hoffmann: Reduction of Nicotine and Tar in Tobacco and in Cigarettes Through Agricultural Techniques; in: Smoking and Health: I. Modifying the Risk for the Smoker; Proc. $3^{\text {rd }}$ World Conf. on Smoking and Health; edited by E.L. Wynder et al., US Gov. Print. Off., Washington, DC, 1976, pp. 35-48.

168. Wynder, E.L. and D. Hoffmann: Tobacco and tobacco smoke; Semin. Oncol. 3 (1976) 5-15.

169. Wynder, E.L., D. Hoffmann, and G.B. Gori (Editors): Smoking and Health: I. Modifying the Risk for the Smoker; Proc. $3^{\text {rd }}$ World Conf. on Smoking and Health 1975, US Gov. Print. Off., Washington, DC, 1976.

170. Brunnemann, K.D., J.D. Adams, and D. Hoffmann: Nonvolatile $N$-Nitrosamines: Analysis in Tobacco and Tobacco 
Smoke by HPLC-TEA; presented at the $31^{\text {st }}$ TCRC, Greensboro, NC, 1977, No. 52.

171. Brunnemann, K.D., G. Stahnke, and D. Hoffmann: Volatile Pyridines: Quantitative Analysis in Main- and Sidestream Smoke of Cigarettes and Cigars; presented at the $31^{\text {st }}$ TCRC, Greensboro, NC, 1977, No. 36.

172. Brunnemann, K.D., L. Yu, and D. Hoffmann: [Chemical Studies on Tobacco Smoke. XVII.] Assessment of carcinogenic volatile $N$-nitrosamines in tobacco and in mainstream and sidestream smoke from cigarettes; Cancer Res. 37 (1977) 3218-3222.

173. Brunnemann, K.D., L. Yu, and D. Hoffmann: Chemical studies on tobacco smoke. XLIX. Gas chromatographic determination of hydrogen cyanide and cyanogen in tobacco smoke; J. Anal. Toxicol. 1 (1977) 38-42.

174. Dong, M., D. Hoffmann, D.C. Locke, and E. Ferrand: Short Communication: The occurrence of caffeine in the air of New York City; Atmos. Environ. 11 (1977) 651-653.

175. Dong, M.W., D.C. Locke, and D. Hoffmann: Characterization of aza-arenes in the basic organic portion of suspended particulate matter; Environ. Sci. Technol. 11 (1977) 612-618.

176. Dong, M., D.C. Locke, and D. Hoffmann: Separation of azaarenes by high pressure liquid chromatography; J. Chromatogr. Sci. 15 (1977) 32-35.

177. Dong, M., I. Schmeltz, R. Jacobs, and D. Hoffmann: Azaarenes in Tobacco Smoke; presented at the $31^{\text {st }}$ TCRC, Greensboro, NC, 1977, No. 43.

178. Hecht, S.S., S. Carmella, and D. Hoffmann: Hydroxyphenyl Alcohols in Tobacco and Tobacco Smoke; presented at the $31^{\text {st }}$ TCRC, Greensboro, NC, 1977, No. 51.

179. Hecht, S.S., C.B. Chen, M. Dong, R.M. Ornaf, D. Hoffmann, and T.C. Tso: Chemical Studies on Tobacco Smoke. LI. Studies on Non-volatile Nitrosamines in Tobacco. Beitr. Tabakforsch. 9 (1977) 1-6.

180. Hecht, S.S., I. Schmeltz, and D. Hoffmann: Chemical Studies on Tobacco Smoke. LVIII. Nitrogenous compounds in cigarette smoke and their possible precursors; presented at the $31^{\text {st }}$ TCRC, Greensboro, NC, 1977, No. 3; in: Rec. Adv. Tobacco Sci. 3 (1977) 59-93.

181. Hilfrich, J., S.S. Hecht, and D. Hoffmann: A Study of Tobacco Carcinogenesis. XV. Effects of $N^{\prime}$-nitrosonornicotine and $N$ '-nitrosoanabasine in Syrian golden hamsters; Cancer Lett. 2 (1977) 169-176.

182. Hoffmann, D., M. Dong, and S.S. Hecht: Chemical Studies on Tobacco Smoke. LII. Origin in tobacco smoke of $N^{\prime}$ nitrosonornicotine, a tobacco-specific carcinogen: Brief Communication; J. Natl. Cancer Inst. 58 (1977) 1841-1844.

183. Hoffmann, D., S.S. Hecht, I. Schmeltz, and E.L. Wynder: Polynuclear aromatic hydrocarbons: Occurrence, formation and carcinogenicity; in: Proc. Symp. Structural Correlates of Carcinogenesis and Mutagenesis: A Guide to Testing Priorities, FDA, Annapolis, MD, 1977, pp. 120-128.

184. Hoffmann, D. and E.L. Wynder: The less harmful cigarette: present and future; World Smoking Health 2 (1977) 30-34

185. Hoffmann, D. and E.L. Wynder: Organic Particulate Pollutants. Chemical Analysis and Bioassays for Carcinogenicity; in: Air Pollution; edited by A. C. Stern, Academic Press, New York, NY, 1977, pp. 361-455.

186. Patrianakos, C., K.D. Brunnemann, and D. Hoffmann: Aromatic Amines in Cigarette Smoke; presented at the $31^{\text {st }}$ TCRC, Greensboro, NC, 1977, No. 44

187. Schmeltz, I., S. Abidi, and D. Hoffmann: [Chemical studies on tobacco smoke. XLVIII.] Tumorigenic agents in unburned processed tobacco: $N$-nitrosodiethanolamine and 1,1dimethylhydrazine; Cancer Lett. 2 (1977) 125-131.

188. Schmeltz, I. and D. Hoffmann: [Chemical Studies on Tobacco Smoke. L.] Nitrogen-containing compounds in tobacco and tobacco smoke. Chem. Rev. 77 (1977) 295-311.
189. Schmeltz, I., D. Hoffmann, and B. Toth: Hydrazines: Occurence, analysis and carcinogenic activity as related to structure; in: Proc. Symp. Structural Correlates of Carcinogenesis and Mutagenesis: A Guide to Testing Priorities, FDA, Annapolis, MD, 1977, pp. 172-178.

190. Schmeltz, I., J. Tosk, G. Jacobs, and D. Hoffmann: [Chemical Studies on Tobacco Smoke. XXXV.] The redox potential and quinone content of cigarette smoke; Anal. Chem. 49 (1977) 1924-1929.

191. Schmeltz, I., A. Wenger, D. Hoffmann, and T.C. Tso: Use of Radioactive Tracers to Determine Cigarette Smoke Components that Arise from Nicotine During Tobacco Combustion; presented at the $31^{\text {st }}$ TCRC, Greensboro, NC, 1977, No. 17

192. Stellman, J.M. and D. Hoffmann: Occupational bladder cancer; Lancet 310 (1977) 563-564.

193. Toth, B., L. Wallcave, K. Patil, I. Schmeltz, and D. Hoffmann: Induction of tumors in mice with the herbicide succinic acid 2,2-dimethylhydrazine; Cancer Res. 37 (1977) 3497-3500.

194. Adams, J.D., K.D. Brunnemann, and D. Hoffmann: Determination of Nitric Oxide in Unaged Smoke by GSC-TEA; presented at the $32^{\text {nd }}$ TCRC, Montreal, Canada, 1978, No. 36.

195. Brunnemann, K.D., J.D. Adams, D.P.S. Ho, and D. Hoffmann: The influence of tobacco smoke on indoor atmospheres. II. Volatile and tobacco specific nitrosamines in main- and sidestream smoke and their contribution to indoor pollution; in: Proc. $4^{\text {th }}$ Joint Conf. on Sensing of Environmental Pollutants, Am. Chem. Soc., New Orleans, LA, 1978, pp. 876-880

196. Brunnemann, K.D. and D. Hoffmann: Chemical Studies on Tobacco Smoke. LIX. Analysis of volatile nitrosamines in tobacco smoke and polluted indoor environments; in: Environmental Aspects of $N$-Nitroso Compounds, IARC Sci. Publ. 19 (1978) 343-356.

197. Brunnemann, K.D., G. Stahnke, and D. Hoffmann: Chemical Studies on Tobacco Smoke. LXI. Volatile pyridines: quantitative analysis in mainstream and sidestream smoke of cigarettes and cigars; Anal. Lett. A-11 (1978) 545-560.

198. Carmella, S., S.S. Hecht, and D. Hoffmann: Subfractionation of the Weakly Acidic Fraction of Cigarette Smoke Condensate by Preparative High Pressure Liquid Chromatography; presented at the $32^{\text {nd }}$ TCRC, Montreal, Canada, 1978, No. 42.

199. Chen, C.B., S.S. Hecht, and D. Hoffmann: [A Study of Chemical Carcinogenesis. XI.] Metabolic $\alpha$-hydroxylation of the tobacco-specific carcinogen, $N$ '-nitrosonornicotine; Cancer Res. 38 (1978) 3639-3645.

200. Chen, C.B., S.S. Hecht, E. LaVoie, and D. Hoffmann: Denitrosation of Tobacco Specific Nitrosamines by $\alpha$ Hydroxylation: An Approach to Their Reduction in Tobacco; presented at the $32^{\text {nd }}$ TCRC, Montreal, Canada, 1978 , No. 48.

201. Chen, C.B., G.D. McCoy, S.S. Hecht, D. Hoffmann, and E.L. Wynder: [A Study of Chemical Carcinogenesis. X.] High pressure liquid chromatographic assay for $\alpha$ hydroxylation of $N$-nitrosopyrrolidine by isolated rat liver microsomes; Cancer Res. 38 (1978) 3812-3816.

202. Dong, M., I. Schmeltz, and D. Hoffmann: Purification of quinolines for bioassay by preparative high pressure liquid chromatography; J. Chromatogr. 150 (1978) 269-272.

203. Dong, M., I. Schmeltz, E. Jacobs, and D. Hoffmann: [Chemical Studies on Tobacco Smoke. LV.] Aza-arenes in tobacco smoke; J. Anal. Toxicol. 2 (1978) 21-25.

204. Dong, M., I. Schmeltz, E. LaVoie, and D. Hoffmann: Azaarenes in the respiratory environment: analysis and assays for mutagenicity; in: Carcinogenesis - Polynuclear Aromatic Hydrocarbons, Vol. 3; edited by R.W. Jones and R.I. Freu- 
denthal, Raven Press, New York, NY, 1978, pp. 97-108.

205. Hecht, S.S., S. Carmella, and D. Hoffmann: Chemical Studies on Tobacco Smoke. LIV. Determination of hydroxybenzyl alcohols and hydroxyphenyl ethanols in tobacco and tobacco smoke; J. Anal. Toxicol. 2 (1978) $56-59$.

206. Hecht, S.S., C.B. Chen, N. Hirota, R.M. Ornaf, T.C. Tso, and D. Hoffmann: [A Study of Tobacco Carcinogenesis. XVI.] Tobacco-specific nitrosamines: Formation from nicotine in vitro and during tobacco curing, and carcinogenicity in strain A mice; J. Natl. Cancer Inst. 60 (1978) 819-824.

207. Hecht, S.S., C.B. Chen, and D. Hoffmann: [A Study of Chemical Carcinogenesis. VI.] Evidence for metabolic $\alpha$ hydroxylation of $\mathrm{N}$-nitrosopyrrolidine; Cancer Res. 38 (1978) 215-218.

208. Hecht, S.S., C.B. Chen, E.J. LaVoie, and D. Hoffmann: Formation and metabolism of tobacco-specific $N$-nitrosamines in leaf; presented at the CORESTA Symposium Sofia, Bulgaria, 1978, No. S16.

209. Hecht, S.S., C.B. Chen, R.M. Ornaf, D. Hoffmann, and T.C. Tso: Chemical Studies on Tobacco Smoke. LVI. Tobaccospecific nitrosamines: origins, carcinogenicity and metabolism; in: Environmental Aspects of $N$-Nitroso Compounds, IARC Sci. Publ. 19 (1978) 395-413.

210. Hecht, S.S., C.B. Chen, R.M. Ornaf, E. Jacobs, J.D. Adams, and D. Hoffmann: Chemical Studies on Tobacco Smoke. LII. Reaction of nicotine and sodium nitrite: Formation of nitrosamines and fragmentation of the pyrrolidine ring; J. Org. Chem. 43 (1978) 72-76.

211. Hecht, S.S., N. Hirota, and D. Hoffmann: [A Study of Chemical Carcinogenesis. XII.] Comparative tumor initiating activity of 10-methylbenzo(a)pyrene, 7,10-dimethylbenzo $(a)$ pyrene, and benzo $(a)$ pyrene; Cancer Lett. 5 (1978) 179-183.

212. Hecht, S.S., N. Hirota, M. Loy, and D. Hoffmann: [A Study of Chemical Carcinogenesis. VIII.] Tumor initiating activity of fluorinated 5-methylchrysenes; Cancer Res. 38 (1978): 1694-1698.

213. Hecht, S.S., E. LaVoie, R. Mazzarese, S. Amin, V. Bedenko, and D. Hoffmann: [A Study of Chemical Carcinogenesis. IX.] 1,2-Dihydro-1,2-dihydroxy-5-methylchrysene, a major activated metabolite of the environmental carcinogen, 5methylchrysene; Cancer Res. 38 (1978) 2191-2194.

214. Hecht, S.S., M. Loy, R. Mazzarese, and D. Hoffmann: A Study of Chemical Carcinogenesis. V. On the Carcinogenicity of 5-Methylchrysene: Structure-activity Studies and Metabolism; in: Polynuclear Aromatic Hydrocarbons and Cancer; edited by H.V. Gelboin and P.O. Ts'o, Academic Press, New York, NY, 1978, pp. 119-130.

215. Hecht, S.S., M. Loy, R. Mazzarese, and D. Hoffmann: A Study of Chemical Carcinogenesis. VII. Synthesis and mutagenicity of modified chrysenes related to the carcinogen, 5-methylchrysene; J. Med. Chem. 21 (1978) 38-44.

216. Hilfrich, J., I. Schmeltz, and D. Hoffmann: [A Study of Tobacco Carcinogenesis. XVII.] Effects of $N$-nitrosodiethanolamine and 1,1-diethanolhydrazine in Syrian golden hamsters; Cancer Lett. 4 (1978) 55-60.

217. Hoffmann, D., K.D. Brunnemann, and J. Adams: Analysis of selected components in the smoke of little cigars; presented at the CORESTA Symposium Sofia, Bulgaria, 1978, No. S12.

218. Hoffmann, D., I. Schmeltz, S.S. Hecht, K.D. Brunnemann, and E.L. Wynder: Volatile Carcinogens: Occurrence, Formation and Analysis; in: Prevention and Detection of Cancer, Part I: Prevention; edited by H.E. Nieburgs, Marcel Dekker, New York, NY, 1978, pp. 1943-1959.

219. Hoffmann, D., I. Schmeltz, S.S. Hecht, and E.L. Wynder: Tobacco Carcinogenesis; in: Polycyclic Hydrocarbons and Cancer, Vol. 1: Chemistry; edited by H.V.. Gelboin and P.O.
Ts'o, Academic Press, New York, NY, 1978, pp. 85-117.

220. Hoffmann, D. and E.L. Wynder: Identification and reduction of carcinogens in the respiratory environment; Zentralbl. Bakteriol. Parasitenkd. Infektionskr. Hyg. Orig. B, 166 (1978) 113-135.

221. Schmeltz, I., K.D. Brunnemann, and D. Hoffmann: Analytical Methods for Polynuclear Hydrocarbons, in: Prevention and Detection of Cancer, Part I: Prevention; edited by H.E. Nieburgs, Marcel Dekker, New York, NY, 1978, pp. 1973-1992.

222. Schmeltz, I., K.G. Chiong, and D. Hoffmann: [Chemical Studies on Tobacco Smoke. LX.] Formation and determination of ethyl carbamate in tobacco and tobacco smoke; J. Anal. Toxicol. 2 (1978) 265-268.

223. Schmeltz, I., J. Tosk, H. Hilfrich, N. Hirota, D. Hoffmann, and E.L Wynder: Bioassays of Naphthalene and Alkylnaphthalene for Co-carcinogenic Activity. Relation to Tobacco Carcinogenesis; in: Carcinogenesis - A Comprehensive Survey; edited by R.W. Jones and R.I. Freudenthal, Raven Press, New York, NY, 1978, pp. 47-60.

224. Schmeltz, I., A. Wenger, D. Hoffmann, and T.C. Tso: Chemical Studies on Tobacco Smoke. LIII. Use of radioactive tobacco isolates for studying the formation of smoke components; J. Agr. Food Chem. 26 (1978) 234-239.

225. Weiss, L., M. Loy, S.S. Hecht, and D. Hoffmann: A Study of Chemical Carcinogenesis. IV. Synthesis of the carbon-14 labelled carcinogens 5-methylchrysene, 2-methylaniline, and 3-methyl-2-naphthylamine; J. Labelled Compd. Radiopharm. 14 (1978) 119-131.

226. Wynder, E.L., D. Hoffmann, G.D. McCoy, L.A. Cohen, and B.S. Reddy: Tumor Promotion and Cocarcinogenesis as Related to Man and His Environment; in: Carcinogenesis, Vol. 2: Mechanisms of Tumor Promotion and Cocarcinogenesis; edited by J. Slaga et al., Raven Press, New York, NY, 1978 pp. $59-77$.

227. Amin, S., S.S. Hecht, E. LaVoie, and D. Hoffmann: A Study of Chemical Carcinogenesis. XIX. Synthesis and mutagenicity of 5,11-dimethylchrysene and some methyl-oxidized derivatives of 5-methylchrysene; J. Med. Chem. 22 (1979) 1336-1340.

228. Carmella, S., S.S. Hecht, and D. Hoffmann: Quantitative Analysis of Alkyl-2-hydroxy-2-cyclopentene-1-ones in Tobacco Smoke; presented at the $33^{\text {rd }}$ TCRC, Lexington, KY, 1979, No. 54.

229. DeVera, N., I. Schmeltz, S.S. Hecht, and D. Hoffmann: Moderately polar non-PAH neutral components in cigarette smoke; presented at the $33^{\text {rd }}$ TCRC, Lexington, KY, 1979, No. 49.

230. Hecht, S.S., S. Amin, A. Rivenson, and D. Hoffmann: A Study of Chemical Carcinogenesis. XX. Tumor initiating activity of 5,11-dimethylchrysene, 5,12-dimethylchrysene and 5-methylchrysene; Cancer Lett. 8 (1979) 65-70.

231. Hecht, S.S., C.B. Chen, and D. Hoffmann: A Study of Tobacco Carcinogenesis. XVII. Tobacco-specific nitrosamines: Occurrence, formation, carcinogenicity, and metabolism; Acc. Chem. Res. 12 (1979) 92-98.

232. Hecht, S.S., C.B. Chen, G.D. McCoy, and D. Hoffmann: A Study of Tobacco Carcinogenesis. XVIII. Tobacco-specific nitrosamines: Occurrence, carcinogenicity, and metabolism; in: Proceedings $8^{\text {th }}$ Northeastern Regional Meeting, Am. Chem. Soc. Symp. Ser. 101 (1979) 125-152.

233. Hecht, S.S., C.B. Chen, G.D. McCoy, D. Hoffmann, and L.A. Domellöf: [A Study of Chemical Carcinogenesis. XVIII.] $\alpha$-Hydroxylation of $N$-nitrosopyrrolidine and $N$ 'nitrosonornicotine by human liver microsomes; Cancer Lett. 8 (1979) 35-41.

234. Hecht, S.S., E. LaVoie, and D. Hoffmann: A Study of Chemical Carcinogenesis. XIII. Structure-activity relationships in polynuclear aromatic hydrocarbons; in: Proc. 
Lawrence Berkeley Lab. Conf. on Carbonaceous Particles in the Atmosphere; edited by T. Novakov, Natl. Techn. Inform. Serv., US Dept. Commerce, Springfield, VA, 1979, pp. $177-186$.

235. Hecht, S.S., E. LaVoie, R. Mazzarese, N. Hirota, T. Ohmori, and D. Hoffmann: [A Study of Chemical Carcinogenesis. XVI.] Comparative mutagenicity, tumor-initiating activity, carcinogenicity, and in vitro metabolism of fluorinated 5methylchrysenes; J. Natl. Cancer Inst. 63 (1979) 855-861.

236. Hecht, S.S., R. Mazzarese, S. Amin, E.J. LaVoie, and D. Hoffmann: A Study of Chemical Carcinogenesis. XV. On the Metabolic Activation of 5-Methylchrysene; in: Polynuclear Aromatic Hydrocarbons; edited by P.W. Jones and P. Leber, Ann Arbor Sci. Publ., Ann Arbor, MI, 1979, pp. 733-752.

237. Hoffmann, D., J.D. Adams, K.D. Brunnemann, and S.S Hecht: [Chemical Studies on Tobacco Smoke. LXII.] Assessment of tobacco-specific $N$-nitrosamines in tobacco products; Cancer Res. 39 (1979) 2505-2509.

238. Hoffmann, D., J.D. Adams, and E.L. Wynder: [Chemical Studies on Tobacco Smoke. LXV.] Formation and analysis of carbon monoxide in cigarette mainstream and sidestream smoke; Prev. Med. 8 (1979) 344-350.

239. Hoffmann, D., K.D. Brunnemann, I. Schmeltz, and E.L. Wynder: Trace Analysis in Respiratory carcinogenesis; in: Trace Organic Analysis: A New Frontier in Analytical Chemistry; edited by H.S. Hertz and S.N. Chester, Natl. Bureau of Standards Special Publ. No. 519, US Govt. Print. Off., Washington, DC, 1979, pp. 131-141.

240. Hoffmann, D., A. Rivenson, S.S. Hecht, J. Hilfrich, N. Kobayashi, and E.L. Wynder: Model studies in tobacco carcinogenesis with the Syrian golden hamster; Progr. Exp. Tumor Res. 24 (1979) 370-390.

241. LaVoie, E., V. Bedenko, N. Hirota, S.S. Hecht, and D. Hoffmann: A Comparison of the Mutagenicity, Tumorinitiating Activity and Complete Carcinogenicity of Polynuclear Aromatic Hydrocarbons; in: Polynuclear Aromatic Hydrocarbons; edited by P.W. Jones and P. Leber, Ann Arbor Sci. Publ., Ann Arbor, MI, 1979, pp. 705-721.

242. LaVoie, E., L. Tulley, E. Fow, and D. Hoffmann: Mutagenicity of aminophenyl and nitrophenyl ethers, sulfides, and disulfides; Mutat. Res. 67 (1979) 123-131.

243. Patrianakos, C. and D. Hoffmann: Chemical Studies on Tobacco Smoke. LXIV. On the analysis of aromatic amines in cigarette smoke; J. Anal. Toxicol. 3 (1979) 150-154.

244. Piade, J.J, J.D. Adams, and D. Hoffmann: Alkaloids and Nonvolatile $\mathrm{N}$-Nitrosamines in Tobacco and Smoke of French Cigarettes; presented at the $33^{\text {rd }}$ TCRC, Lexington, KY, 1979, No. 56

245. Schmeltz, I., K.D. Brunnemann, and D. Hoffmann: Trace analysis in agricultural products: methods for hydrazines, carbamates, $N$-nitrosodiethanolamine and other compounds; in: Trace Organic Analysis: A New Frontier in Analytical Chemistry; edited by H.S. Hertz and S.N. Chester, Natl. Bureau of Standards Special Publ. No. 519, U.S. Govt. Print. Off., Washington, DC, 1979, pp. 297-309.

246. Schmeltz, I., A. Wenger, D. Hoffmann, and T.C. Tso: Chemical Studies on Tobacco Smoke. LXIII. On the fate of nicotine during pyrolysis and in a burning cigarette; J. Agric. Food Chem. 27 (1979) 602-608.

247. Tosk, J., I. Schmeltz, and D. Hoffmann: Hydrazines as mutagens in a histidine-requiring auxotroph of Salmonella typhimurium; Mutat. Res. 66 (1979) 247-252.

248. Wynder, E.L. and D. Hoffmann: Rauchen und Gesundheit. Die Epidemiologie tabakbedingter Erkrankungen; Therapiewoche 29 (1979) 8747-8757.

249. Wynder, E.L. and D. Hoffmann: Perforated filter-tip cigarettes: effect on tar, nicotine, and carbon monoxide intake; JAMA 241 (1979) 295
250. Wynder, E.L. and D. Hoffmann: Stopping smoking (Letter); New Engl. J. Med. 301 (1979) 390.

251. Wynder, E.L. and D. Hoffmann: Smoking and Health: Pathogenic and Preventive Considerations; Bull. Schweiz. Akad. Med. Wiss. 35 (1979) 83-98.

252. Wynder, E.L. and D. Hoffmann: Tobacco and Health. A societal challenge; New Engl. J. Med. 300 (1979) 894-903.

253. Adams, J.D., J.J. Piade, and D. Hoffmann: The selective reduction of tobacco specific $N$-nitrosamines from cigarette smoke; presented at the $34^{\text {th }}$ TCRC, Richmond, VA, 1980 , No. 50 .

254. Brunnemann, K.D., D. Hoffmann, and T.C. Tso: The fate of diethanolamine in tobacco and cigarette smoke; presented at the $34^{\text {th }}$ TCRC, Richmond, VA, 1980, No. 51

255. Carmella, S., S.S. Hecht, D. Hoffmann, and T.C. Tso: The formation of catechol in cigarette smoke; presented at the $34^{\text {th }}$ TCRC, Richmond, VA, 1980, No. 30.

256. Chen, C.B., S.S. Hecht, G.D. McCoy, and D. Hoffmann: Assays for metabolic $\alpha$-hydroxylation of $N$ '-nitrosonornicotine and $N$-nitrosopyrrolidine and the influence of modifying factors; in: $N$-Nitroso Compounds: Analysis, Formation and Occurrence, IARC Sci. Publ. 31 (1980) 349-359.

257. Hecht, S.S., C.B. Chen, and D. Hoffmann: [A Study of Chemical Carcinogenesis. XXIX.] Metabolic $\beta$-hydroxylation and $N$-oxidation of $N$ '-nitrosonornicotine; J. Med. Chem. 23 (1980) 1175-1178.

258. Hecht, S.S., C.B. Chen, T. Ohmori, and D. Hoffmann: [A Study of Tobacco Carcinogenesis. XIX.] Comparative carcinogenicity in F344 rats of the tobacco-specific nitrosamines, $N$ '-nitrosonornicotine and 4-( $N$-methyl- $N$-nitrosamino)-1-(3-pyridyl)-1-butanone; Cancer Res. 40 (1980) 298-302.

259. Hecht, S.S., C.B. Chen, R. Young, D. Lin, and D. Hoffmann: Metabolism of the tobacco-specific nitrosamines, $N$ 'nitrosonornicotine and 4-( $N$-methyl- $N$-nitrosamino)-1-(3pyridyl)-1-butanone, in: $N$-Nitroso Compounds: Analysis, Formation and Occurrence, IARC Sci. Publ. 31 (1980) $755-765$.

260. Hecht, S.S., E. LaVoie, S. Amin, V. Bedenko, and D. Hoffmann: On the metabolic activation of the benzofluoranthenes, in: Polynuclear Aromatic Hydrcarbons: Chemistry and Biological Effects; edited by A. Bjorseth and A.J. Dennis, Battelle Press, Columbus, OH, 1980, pp. 417-433.

261. Hecht, S.S., A. Rivenson, and D. Hoffmann: Tumor-initiating activity of dihydrodiols formed metabolically from 5methylchrysene; Cancer Res. 40 (1980) 1396-1399.

262. Hoffmann, D., J.D. Adams, J.J. Piade, and S.S. Hecht: Chemical Studies on Tobacco Smoke. LXVIII. Analysis of volatile and tobacco-specific nitrosamines in tobacco products; in: $N$-Nitroso Compounds: Analysis, Formation and Occurrence, IARC Sci. Publ. 31 (1980) 507-516.

263. Hoffmann, D., C.B. Chen, and S.S. Hecht: The role of volatile and nonvolatile $N$-nitrosamines in tobacco carcinogenesis; in: Banbury Report 3: A Safe Cigarette?; edited by G.B. Gori and F.B. Bock, Cold Spring Harbor Laboratory Publ., Cold Spring Harbor, NY, 1980, pp. 113-127.

264. Hoffmann, D., S.S. Hecht, and E.L.Wynder: The role of polynuclear aromatic hydrocarbons in tobacco carcinogenesis; presented at the Polycyclic Aromatic Hydrocarbons Conf. of the Verein Deutscher Ingenieure, Hannover, Germany, 1979; VDI-Ber. 358 (1980) 335-350.

265. Hoffmann, D. and I. Hoffmann: Oncology Overview on Organ Specific Carcinogenicity of Tobacco Products. 1. Epidemiology of Non-Respiratory Tract Cancer and Related Clinical Observations; Internatl. Cancer Res. Data Bank PB80-922907, US Dept. H.H.S., 1980.

266. Hoffmann, D., T.C. Tso, and G.B. Gori: The Less Harmful Cigarette; Prev. Med. 9 (1980) 287-296.

267. Hoffmann, D. and E.L. Wynder: The low yield cigarette 
Editorial; Am. J. Public Health, 70 (1980) 1143-1144; Response to Letter to the Editor; Am. J. Public Health, 71 (1981) 536-537.

268. LaVoie, E.J., S.S. Hecht, S. Amin, V. Bedenko, and D. Hoffmann: Identification of mutagenic dihydrodiols as metabolites of benzo(j)fluoranthene and benzo( $k)$ fluoranthene; Cancer Res. 40 (1980) 4528-4532.

269. LaVoie, E.J., S.S. Hecht, D. Hoffmann, and E.L. Wynder: The less harmful cigarette and tobacco smoke flavors; Banbury Report 3: A Safe Cigarette?; edited by G.B. Gori and F.B. Bock, Cold Spring Harbor Laboratory Publ., Cold Spring Harbor, NY, 1980, pp. 251-260.

270. LaVoie, E., L. Tulley, V. Bedenko, and D. Hoffmann: Mutagenicity, tumor initiating activity and metabolism of tricyclic polynuclear aromatic hydrocarbons; in: Polynuclear Aromatic Hydrocarbons: Chemistry and Biological Effects.; edited by A. Bjorseth and A.J. Dennis, Battelle Press, Columbus, OH, 1980, pp. 1041-1057.

271. Piade, J.J., J.D. Adams, and D. Hoffmann: The semi-volatile and gasphases of cigarette smoke from air cured tobacco: chromatographic profiling and effect of aging; presented at the $34^{\text {th }}$ TCRC, Richmond, VA, 1980, No. 16 .

272. Piade, J.J. and D. Hoffmann: Chemical Studies on Tobacco Smoke. LXVII. Quantitative determination of alkaloids in tobacco by liquid chromatography; J. Liq. Chromatogr. 3 (1980) 1505-1515.

273. Rivenson, A., T. Ohmori, S.S. Hecht, and D. Hoffmann: Organotropic carcinogenicity of tobacco-specific $N$-nitrosamines, in: Biology of the Cancer Cell; edited by K. Letnansky, Kugler Publ., Amsterdam, The Netherlands, 1980, pp. $51-62$.

274. Rühl, C., J.D. Adams, and D. Hoffmann: Chemical Studies on Tobacco Smoke. LXVI. Comparative assessment of volatile and tobacco-specific $N$-nitrosamines in the smoke of selected cigarettes from the USA, West Germany and France; J. Anal. Toxicol. 4 (1980) 255-259.

275. Schmeltz, I., K.D. Brunnemann, and D. Hoffmann: Azaarenes and other nitrogen-containing compounds in the respiratory environment. Proc. Am. Inst. Chem. Engineers Symposium Ser. 196, 1980, pp. 312-320.

276. Schmeltz, I., A. Wenger, and D. Hoffmann: TLC in the Analysis of the Respiratory Environment; in: Thin-layer Chromatography: Quantitative, Environmental, and Clinical Applications; edited by J.C. Touchstone and D. Rogers, J. Wiley and Sons, New York, NY, 1980, pp. 325-347.

277. Adams, J.D., A. Castonguay, S.J. Lee, N. Vinchkoski, and D. Hoffmann: Formation and Transfer of 4-(Methylnitrosamino)-1-(3-pyridyl)-butanone (NNK) During Smoking; pres. at the $35^{\text {th }}$ TCRC, Winston-Salem, NC, 1981, No. 49.

278. Amin, S., V. Bedenko, E. LaVoie, S.S. Hecht, and D. Hoffmann: Study of chemical carcinogenesis. XXII. Synthesis of dihydrodiols as potential proximate carcinogens of benzofluoranthenes; J. Org. Chem. 46 (1981) 2573-2578.

279. Amin, S., S.S. Hecht, and D. Hoffmann: Synthesis of angular ring methoxy-5-methylchrysenes and 5-methylchrysenols; J. Org. Chem. 46 (1981) 2394-2398.

280. Brunnemann, K.D. and D. Hoffmann: [Chemical Studies on Tobacco Smoke. LXIX.] Assessment of the carcinogenic $N$ nitrosodiethanolamine in tobacco products and tobacco smoke; Carcinogenesis 2 (1981) 1123-1127.

281. Brunnemann, K.D. and D. Hoffmann: Concurrent Gas Chromatographic Determination of Volatile, Nonvolatile, and Tobacco Specific $N$-Nitrosamines; presented at the $35^{\text {th }}$ TCRC, Winston-Salem, NC, 1981, No. 33.

282. Carmella, S., S.S. Hecht, and D. Hoffmann: Precursor Studies on Catechol in Cigarette Smoke; presented at the $35^{\text {th }}$ TCRC, Winston-Salem, NC, 1981, No. 50.

283. El-Bayoumy, K., E.J. LaVoie, S.S. Hecht, E.A. Fow, and D. Hoffmann: The influence of methyl substitution on the mutagenicity of nitronaphthalenes and nitrobiphenols; Mutat. Res. 81 (1981) 143-153.

284. Hecht, S.S., S. Carmella, and D. Hoffmann: [Chemical Studies on Tobacco Smoke. LXX.] Quantitative Analysis of Alkyl-2-hydroxy-2-cyclopenten-1-ones in Tobacco Smoke; J. Agric. Food Chem. 29 (1981) 401-404.

285. Hecht, S.S., S. Carmella, H. Mori, and D. Hoffmann: A Study of Tobacco Carcinogenesis. XX. Role of Catechol as a Major Cocarcinogen in the Weakly Acidic Fraction of Smoke Condensate; J. Natl. Cancer Inst. 66 (1981) 163-169.

286. Hecht, S.S., C.B. Chen, R. Young, and D. Hoffmann: [Chemical Studies on Tobacco Smoke. LXXI.] Mass Spectra of Tobacco-specific Nitrosamines, Their Metabolites, and Related Compounds; Beitr. Tabakforsch. Int. 11 (1981) 57-66.

287. Hecht, S.S., E.J. LaVoie, V. Bedenko, D. Hoffmann, D.J. Sardella, E. Boger, and R. Lehr: A Study of Chemical Carcinogenesis. XXXII. On the Metabolic Activation of Dibenzo $[a, i]$ pyrene and Dibenzo $[a, h]$ pyrene; in: Polynuclear Aromatic Hydrocarbons: Chemical Analysis and Biological Fate; edited by M. Cooke and A.J.Dennis, Battelle Press, Columbus, OH, 1981, pp. 43-54.

288. Hecht, S.S., E.J. LaVoie, V. Bedenko, L. Pingaro, S Katayama, D. Hoffmann, D.J. Sardella, E. Boger, and R.E. Lehr: Reduction of tumorigenicity and of dihydrodiol formation by fluorine substitution in the angular rings of dibenzo[ $a, i]$ pyrene; Cancer Res. 41 (1981) 4341-4345.

289. Hoffmann, D. and J.D. Adams: [A Study of Tobacco Carcinogenesis. XXIII.] Carcinogenic tobacco-specific $N$ nitrosamines in snuff and in the saliva of snuff dippers; Cancer Res. 41 (1981) 4305-4308.

290. Hoffmann, D., J.D. Adams, K.D. Brunnemann, and S.S Hecht: Formation, occurrence and carcinogenicity of $\mathrm{N}$ nitrosamines in tobacco products; in: $N$-Nitroso Compounds; edited by R.A. Scanlan and S.R. Tannenbaum, Am. Chem. Soc. Symp. Ser. 174, Washington, DC, 1981, pp. 247-273.

291. Hoffmann, D., A. Castonguay, A. Rivenson, and S.S. Hecht: [A Study of Tobacco Carcinogenesis. XXII.] Comparative carcinogenicity and metabolism of 4-(methylnitrosamino)-1(3-pyridyl)-1-butanone and N'-nitrosonornicotine in Syrian golden hamsters; Cancer Res. 41 (1981) 2386-2393.

292. Hoffmann, D. and I. Hoffmann: Oncology overview on organ specific carcinogenicity of tobacco products. 2 . Bioassays, physicochemical analysis, and other experimental evidence; Internatl. Cancer Res. Data Bank PB81-922902, US Dept. H.H.S., 1981.

293. LaVoie, E.J., A. Govil, G. Briggs, and D. Hoffmann: Mutagenicity of aminocarbazoles and nitrocarbazoles; Mutat. Res. 90 (1981) 337-344.

294. LaVoie, E.J., A. Rivenson, B. Bedenko, E. Kolb, T. Ohmori, and D. Hoffmann: Carcinogenicity in Syrian golden hamsters of $N$-nitrosamines formed during nitrosation of spermidine; Cancer Detect. Prev. 4 (1981) 79-84.

295. LaVoie, E.J., L. Tulley-Freiler, V. Bedenko, and D. Hoffmann: On the metabolic activation of methylated phenanthrenes; presented at the $72^{\text {nd }}$ Ann. Meeting Am. Assoc. Cancer Res., 1981, No. 370.

296. LaVoie, E.J., L. Tulley, V. Bedenko, and D. Hoffmann: Mutagenicity and methylated fluorenes and benzofluorenes; Mutat. Res. 91 (1981) 167-176.

297. LaVoie, E.J., L. Tulley-Freiler, V. Bedenko, Z. Girach, and D. Hoffmann: Comparative Studies on the Tumor-initiating Activity and Metabolism of Methylfluorenes and Methylbenzofluorenes; in: Polynuclear Aromatic Hydrocarbons: Chemical Analysis and Biological Fate; edited by M. Cooke and A.J. Dennis, Battelle Press, Columbus, OH, 1981, pp. 417-427.

298. LaVoie, E.J., L. Tulley-Freiler, V. Bedenko, and D. Hoffmann: Mutagenicity, tumor initiating activity and metabo- 
lism of methylphenanthrenes; Cancer Res. 41 (1981) 3441-3447.

299. Melikian, A., E.J. LaVoie, D. Hoffmann, and E.L. Wynder: Volatile nitrosamines: analysis in breast fluid and blood of non-lactating women; Food Cosmet. Toxicol. 19 (1981) 757-759.

300. Adams, J.D., K.D. Brunnemann, S.S. Hecht, and D. Hoffmann: Biogenesis and chemistry of alkaloid-derived $\mathrm{N}$ nitrosamines; presented at the $184^{\text {th }}$ Natl. Mtg., Am. Chem. Soc., 1982, No. 66.

301. Adams, J.D., E.J. LaVoie, and D. Hoffmann: Analysis of methylated polynuclear aromatic hydrocarbons by capillary gas chromatography. Influence of temperature on the pyrosynthesis of anthracene, phenanthrene, and their methylated derivatives; J. Chromatogr. Sci. 20 (1982) 274-277.

302. Adams, J.D., A. Shigematsu, P. Owens, E.J. LaVoie, and D. Hoffmann: Quinolines and methylquinolines in the mainstream smoke of commercial cigarettes; presented at the $36^{\text {th }}$ TCRC, Raleigh, NC, 1982, No. 38.

303. Brunnemann, K.D., S.S. Hecht, and D. Hoffmann: $N$ Nitrosamines: Environmental occurrence, in vivo formation and metabolism; J. Toxicol. Clin. Toxicol. 19 (1982) 661-688.

304. Brunnemann, K.D. and D. Hoffmann: [Chemical Studies on Tobacco Smoke. LXXIV.] Pyrolytic origins of major gas phase constituents of cigarette smoke; presented at the $36^{\text {th }}$ TCRC, Raleigh, NC, 1982, No. 3; in: Rec. Adv. Tobacco Sci. 8 (1982) 103-140.

305. Brunnemann, K.D., J.C. Scott, and D. Hoffmann: [Chemical Studies on Tobacco Smoke. LXXII.] N-Nitrosomorpholine and other volatile $\mathrm{N}$-nitrosamines in snuff tobacco; Carcinogenesis 3 (1982) 693-696.

306. Carmella, S., S.S. Hecht, D. Hoffmann, and T.C. Tso: Cellulose and modified cellulose as precursors to catechol in cigarette smoke; presented at the $36^{\text {th }}$ TCRC, Raleigh, NC, 1982, No. 39.

307. Castonguay, A., S.S. Hecht, D. Hoffmann, G.D. Stoner, and H.A.J. Schut: Metabolism of tobacco-specific nitrosamines in cultured human tissues; presented at the $73^{\text {rd }}$ Ann. Meeting Am. Assoc. Cancer Res., 1982, No. 333.

308. El-Bayoumy, K., S.S. Hecht, and D. Hoffmann: [A Study of Chemical Carcinogenesis. XLVI.] Comparative tumor initiating activity on mouse skin of 6-nitrobenzo[ $a]$ pyrene, 6-nitrochrysene, 3-nitropyrene, 1-nitropyrene and their parent hydrocarbons; Cancer Lett. 16 (1982) 333-337.

309. Gutenmann, W.H., C.A. Bache, D.J. Lisk, D. Hoffmann, J.D. Adams, and D.C. Elfving: Cadmium and nickel in smoke of cigarettes prepared from tobacco cultured on municipal sludge-amended soil; J. Toxicol. Environ. Health 10 (1982) 423-431.

310. Hecht, S.S., A. Castonguay, F.-L. Chung, D. Hoffmann, and G.D. Stoner: Recent studies on the metabolic activation of cyclic nitrosamines; in: Banbury Report 12: Nitrosamines and Human Cancer; edited by P.N. Magee, Cold Spring Harbor Laboratory Publ., Cold Spring Harbor, NY, 1982, pp. 103-120.

311. Hecht, S.S., G.D. McCoy, B.C. Chen, and D. Hoffmann: The metabolism of cyclic nitrosamines; in: $N$-Nitroso Compounds; edited by R.A. Scanlan and S.R. Tannenbaum, Am. Chem. Soc. Symp. Ser. 174, Washington, DC, 1982, pp. 49-75.

312. Hecht, S.S., R. Young, A. Rivenson, and D. Hoffmann: On the metabolic activation of $N$-nitrosomorpholine and $N$ 'nitrosonornicotine: effects of deuterium substitution; in: $N$ Nitroso Compounds: Occurrence and Biological Effects, IARC Sci. Publ. 41 (1982) 499-507.

313. Hoffmann, D., J.D. Adams, A. Rivenson, and S.S. Hecht: Alkaloid-derived $N$-nitrosamines, a major group of tobacco carcinogens; presented at the $13^{\text {th }}$ International Cancer
Congress, Seattle, 1982, No. 2292.

314. Hoffmann, D., J.D. Adams, K.D. Brunnemann, A. Rivenson, and S.S. Hecht: Tobacco-specific $N$-Nitrosamines: Occurrence and Bioassays; in: $N$-Nitroso Compounds: Occurrence and Biological Effects, IARC Sci. Publ. 41 (1982) 309-318.

315. Hoffmann, D., J.D. Adams, N. Vinchkoski, and T.C. Tso: On the fate of nicotine $-{ }^{14} \mathrm{C}$ during leaf curing and smoking; presented at the CORESTA Symposium Winston-Salem, NC, 1982, No. S04.

316. Hoffmann, D., K.D. Brunnemann, J.D. Adams, A. Rivenson, and S.S. Hecht: $N$-Nitrosamines in tobacco carcinogenesis; in: Banbury Report 12: Nitrosamines and Human Cancer; edited by P.N. Magee, Cold Spring Harbor Laboratory Publ., Cold Spring Harbor, NY, 1982, pp. 211-225.

317. Hoffmann, D., K.D. Brunnemann, A. Rivenson, and S.S. Hecht: $N$-Nitrosodiethanolamine: Analysis, formation in tobacco products and carcinogenicity in Syrian golden hamsters; presented at the $7^{\text {th }}$ International Meeting on $N$ Nitroso Compounds, Tokyo, Japan, 1981; in: $N$-Nitroso Compounds: Occurrence and Biological Effects, IARC Sci. Publ. 41 (1982) 299-307.

318. Hoffmann, D. and I. Hoffmann: Experimental Carcinogenesis with Tobacco Products; in: Health Consequences of Smoking - Cancer. A Report of the Surgeon General, Part III, US Department of Health and Human Services, Washington, DC, DHHS (PHS) 82-50179, 1982, pp. 181-235.

319. Hoffmann, D., E.J. LaVoie, and S.S. Hecht: Polynuclear aromatic hydrocarbons: effect of chemical structure on tumorigenicity; in: Polynuclear Aromatic Hydrocarbons: Physical and Biological Chemistry; edited by M. Cooke et al., Battelle Press, Columbus, OH, 1982, pp. 1-19.

320. Hoffmann, D. and E.L. Wynder: Radioactivity in cigarette smoke; New Engl. J. Med. 307 (1982) 312.

321. Hoffmann, D. and E.L. Wynder: Tobacco and tobacco smoke. A continuing public health issue; Tobacco J. Int. 1 (1982) 83-85.

322. LaVoie, E.J., S. Amin, S.S. Hecht, K. Furuya, and D. Hoffmann: [A Study of Chemical Carcinogenesis. XXXVIII.] Tumor-initiating activity of dihydrodiols of benzo $(b)$ fluoranthene, benzo $(j)$ fluoranthene, and benzo $(k)$ fluoranthene; Carcinogenesis 3 (1982) 49-52.

323. LaVoie, E.J., V. Bedenko, L. Tulley-Freiler, and D. Hoffmann: Tumor-initiating activity and metabolism of polymethylated phenanthrenes; Cancer Res. 42 (1982) 4045-4049.

324. LaVoie, E.J., G. Briggs, V. Bedenko, and D. Hoffmann: Mutagenicity of substituted carbazoles in Salmonella typhimurium; Mutat. Res. 101 (1982) 141-150.

325. LaVoie, E.J., S.S. Hecht, V. Bedenko, and D. Hoffmann: Identification of the mutagenic metabolites of fluoranthene, 2-methylfluoranthene, and 3-methylfluoranthene. Carcinogenesis 3 (1982) 841-846.

326. LaVoie, E.J, A. Shigematsu, and D. Hoffmann: Aromatic amines and $N$-heterocyclics in tobacco distillates; presented at the $184^{\text {th }}$ Natl. Mtg. Am. Chem. Soc., 1982, No. 53.

327. Lee, S.J., J.D. Adams, and D. Hoffmann: On the occurrence and analysis of nitrocatechol(s) in cigarette smoke; presented at the $36^{\text {th }}$ TCRC, 1982, Raleigh, NC, No. 12.

328. Melikian, A.A., E.J. LaVoie, S.S. Hecht, and D. Hoffmann: Influence of a bay region methyl group on formation of 5methylchrysene dihydrodiol epoxide: DNA adducts in mouse skin; Cancer Res. 42 (1982) 1239-1242.

329. Scott, J.C., K.D. Brunnemann, and D. Hoffmann: $N$-Nitrosoproline, an indicator for $\mathrm{N}$-nitrosation of amines in tobacco products; presented at the $36^{\text {th }}$ TCRC, 1982, Raleigh, NC, No. 40.

330. Tso, T.C., J.F. Chaplin, J.D. Adams, and D. Hoffmann: Simple Correlation and Multiple Regression among Leaf and Smoke Characteristics of Burley Tobaccos; Beitr. Tabak- 
forsch. Int. 11 (1982) 141-150.

331. Wynder, E.L. and D. Hoffmann: Tobacco; in: Cancer Epidemiology and Prevention; edited by D. Schottenfeld and J.J.F. Fraumeni, Saunders, Philadelphia, PA, 1982, pp. 277-292 (Chapter 15).

332. Adams, J.D., K.D. Brunnemann, and D. Hoffmann: [Chemical Studies on Tobacco Smoke. LXXV.] Rapid method for the analysis of tobacco-specific $N$-nitrosamines by GLCTEA. J. Chromatogr. 256 (1983) 347-351.

333. Adams, E.A., E.J. LaVoie, and D. Hoffmann: Mutagenicity and metabolism of azaphenanthrenes; in: Polynuclear Aromatic Hydrocarbons - Formation, Metabolism and Measurements; edited by M. Cooke and A.J. Dennis, Battelle Press, Columbus, OH, 1983, pp. 73-87.

334. Adams, J.D., E.J. LaVoie, A. Shigematsu, P. Owens, and D. Hoffmann: [Chemical Studies on Tobacco Smoke. LXXX.] Quinoline and methylquinolines in cigarette smoke: Comparative data and the effect of filtration; J. Anal. Toxicol. 7 (1983) 293-296.

335. Adams, J.D., S.J. Lee, N. Vinchkoski, A. Castonguay, and D. Hoffmann: [Chemical Studies on Tobacco Smoke. LXXIII.] On the formation of the tobacco-specific carcinogen 4-(methylnitrosamino)-1-(3-pyridyl)-1-butanone during smoking; Cancer Lett. 17 (1983) 339-346.

336. Brunnemann, K.D. and D. Hoffmann: GC-TEA of NDELA from tobacco products; in: Environmental Carcinogens Selected Methods of Analysis. Vol. 6: $\mathrm{N}$-Nitroso Compounds, IARC Sci. Publ. 45 (1983) 399-402.

337. Brunnemann, K.D. and D. Hoffmann: $N$-Nitrosodiethanolamine in tobacco and mainstream and sidestream smoke; in: Environmental Carcinogens - Selected Methods of Analysis. Vol. 6: N-Nitroso Compounds, IARC Sci. Publ. 45 (1983) 85-92.

338. Brunnemann, K.D., J. Masaryk, and D. Hoffmann: The role of tobacco stems in the formation of $N$-nitrosamines in tobacco and cigarette mainstream and sidestream smoke; presented at the $37^{\text {th }}$ TCRC, Washington, DC, 1983, No. 6 .

339. Brunnemann, K.D., J. Masaryk, and D. Hoffmann: [Chemical Studies on Tobacco Smoke. LXXXI.] Role of tobacco stems in the formation of $N$-nitrosamines in tobacco and cigarette mainstream and sidestream smoke; J. Agric. Food Chem. 31 (1983) 1221-1224.

340. Brunnemann, K.D., J.C. Scott, and D. Hoffmann: [Chemical Studies on Tobacco Smoke. LXXIX.] $N$-Nitrosoproline, an indicator for $N$-nitrosation of amines in processed tobacco; J. Agric. Food Chem. 31 (1983) 905-909.

341. Carmella, S.C., S.S. Hecht, D. Hoffmann, J.J. Lam, and T.C. Tso: Effects of carboxymethylation of tobacco fiber on smoke catechol levels; presented at the $37^{\text {th }}$ TCRC, Washington, DC, 1983, No. 40.

342. Eisenbrand, G., M. Archer, K.D. Brunnemann, D. Fine, S.S. Hecht, D. Hoffmann, J. Krull, and K.S. Webb: Problems of contamination and artifact formation in nitrosamine sampling and analysis; in: Environmental Carcinogens - Selected Methods of Analysis, Vol. 6: N-Nitroso Compounds, IARC Sci. Publ. 45 (1983) 25-34.

343. Gutenmann, W.H., D.J. Lisk, D. Hoffmann, and J.D. Adams: Selenium in particulates and gaseous fractions of smoke from cigarettes prepared from tobacco grown on flyash-amended soil; J. Toxicol. Environ. Health 12 (1983) 385-393.

344. Hecht, S.S., J.D. Adams, and D. Hoffmann: HPLC-TEA of Tobacco-Specific Nitrosamines, in: Environmental Carcinogens - Selected Methods of Analysis. Vol. 6: N-Nitroso Compounds, IARC Sci. Publ. No., 45 (1983) 429-436.

345. Hecht, S.S., J.D. Adams, and D. Hoffmann: Tobaccospecific Nitrosamines in Tobacco and Tobacco Smoke; in: Environmental Carcinogens - Selected Methods of Analysis. Vol. 6. N-Nitroso Compounds, IARC Sci. Publ. 45 (1983)
93-101.

346. Hecht, S.S., J.D. Adams, S. Numoto, and D. Hoffmann: A Study of Tobacco Carcinogenesis. XXV. Induction of respiratory tract tumors in Syrian golden hamsters by a single dose of 4-(methylnitrosamino)-1-(3-pyridyl)-1butanone (NNK) and the effect of smoke inhalation; Carcinogenesis 4 (1983) 1287-1290.

347. Hecht, S.S., A. Castonguay, and D. Hoffmann: Nasal cavity carcinogens: possible routes of metabolic activation; in: Nasal Tumors in Animals and Man, Vol. 3: Experimental Nasal Carcinogenesis; edited by G. Reznik and S.F. Stinson, CRC Press Inc., Boca Raton, FL, 1983, pp. 201-232.

348. Hecht, S.S., A. Castonguay, A. Rivenson, B. Mu, and D. Hoffmann: Tobacco-specific nitrosamines: carcinogenicity, metabolism, and possible role in human cancer; J. Environ. Sci. Health C1 1 (1983) 1-54.

349. Hoffmann, D., J.D. Adams, and N.J. Haley: [Chemical Studies on Tobacco Smoke. LXXVI.] Reported cigarette smoke values: a closer look; Amer. J. Public Health 73 (1983) 1050-1053.

350. Hoffmann, D. and K.D. Brunnemann: GC-TEA of Volatile Nitrosamines from Tobacco Products; in: Environmental Carcinogens - Selected Methods of Analysis. Vol. 6: NNitroso Compounds, IARC Sci. Publ. 45 (1983) 363-366.

351. Hoffmann, D. and K.D. Brunnemann: [A Study of Tobacco Carcinogenesis.] XXVI. Endogenous formation of $\mathrm{N}$ nitrosoproline in cigarette smokers; Cancer Res. 43 (1983) 5570-5574.

352. Hoffmann, D., K.D. Brunnemann, and K.S. Webb: Volatile nitrosamines in tobacco and mainstream and sidestream smoke and indoor environments; in: Environmental Carcinogens - Selected Methods of Analysis. Vol. 6: N-Nitroso Compounds, IARC Sci. Publ. 45 (1983) 69-83.

353. Hoffmann, D., N.J. Haley, K.D. Brunnemann, J.D. Adams, and E.L. Wynder: Cigarette sidestream smoke: Formation, analysis, and model studies on the uptake by nonsmokers; US-Japan Meeting., New Etiology of Lung Cancer, Honolulu, Hawaii, 1983.

354. Hoffmann, D., N.J. Haley, K.D. Brunnemann, and E.L. Wynder: On the endogenous formation of $N$-nitrosamines in cigarette smokers; presented at the $74^{\text {th }}$ Ann. Meeting Am. Assoc. Cancer Res., 1983, No. 241.

355. Hoffmann, D., N.J. Haley, K.D. Brunnemann, and E.L. Wynder: On the endogenous formation of $N$-nitrosamines in cigarette smokers; Proc. Am. Assoc. Cancer Res. 24 (1983) 61-63.

356. Hoffmann, D. and S.S. Hecht: Tobacco and Tobacco Smoke (Volatile and Tobacco-Specific Nitrosamines). II.2.a: General Aspects; in: Environmental Carcinogens - Selected Methods of Analysis. Vol. 6: N-Nitroso Compounds, IARC Sci. Publ. 45 (1983) 63-67.

357. Hoffmann, D., S.S. Hecht, N.J. Haley, K.D. Brunnemann, J.D. Adams, and E.L. Wynder: Tobacco Carcinogenesis: Metabolic Studies in Humans; in: Human Carcinogenesis; edited by C.C. Harris and H.N. Autrup, Academic Press, New York, NY, 1983, pp. 809-832.

358. Hoffmann, D., S.S. Hecht, and E.L. Wynder: Tumor promoters and cocarcinogens in tobacco carcinogenesis; Environ. Health Perspect. 50 (1983) 247-257.

359. Hoffmann, D., A. Rivenson, J.D. Adams, A. Juchatz, N. Vinchkoski, and S.S. Hecht: [A Study of Tobacco Carcinogenesis. XXIV.] Effects of route of administration and dose on the carcinogenicity of $\mathrm{N}$-nitrosodiethanolamine in the Syrian golden hamster; Cancer Res. 43 (1983) 2521-2524.

360. Hoffmann, D., E.L. Wynder, A. Rivenson, E.J. LaVoie, and S.S. Hecht: Skin Bioassays in Tobacco Carcinogenesis; in: Progress in Experimental Tumor Research. Vol. 26: Skin Painting Techniques and in vivo Carcinogenesis Bioassays; 
edited by F. Homburger, Karger, Basel, Switzerland, 1983, pp. 43-67.

361. LaVoie, E.J., E.A. Adams, and D. Hoffmann: Identification of the metabolites of benzo(f)quinoline and benzo $(h)$ quinoline formed by rat liver homogenate; Carcinogenesis 4 (1983) 1133-1138.

362. LaVoie, E.J., E.A. Adams, A. Shigematsu, and D. Hoffmann: On the metabolism of quinoline and isoquinoline: possible molecular basis for differences in biological activities; Carcinogenesis 4 (1983) 1169-1173.

363. LaVoie, E.J., D.T. Coleman, R.L. Tonne, and D. Hoffmann: Mutagenicity, Tumor Initiating Activity and Metabolism of Methylated Anthracenes, in: Polynuclear Aromatic Hydrocarbons - Formation, Metabolism and Measurements; edited by M. Cooke and A.J.Dennis, Battelle Press, Columbus, OH, 1983, pp. 785-798.

364. LaVoie, E.J., S.S. Hecht, and D. Hoffmann: Molecular basis for the structure-carcinogenicity relationships of polynuclear aromatic hydrocarbons; in: Structure-Activity Correlation as a Predictive Tool in Toxicology. Fundamentals, Methods, and Application; edited by L. Goldberg, Hemisphere Publ. Co., New York, NY, 1983, pp. 263-274.

365. LaVoie, E.J., L. Tulley-Freiler, V. Bedenko, and D. Hoffmann: Mutagenicity of substituted phenanthrenes in Salmonella typhimurium; Mutat. Res. 116 (1983) 91-102.

366. Masaryk, J., K.D. Brunnemann, D. Hoffmann: Model studies on nicotine analogues, synthesis and nitrosation reactions; presented at the $37^{\text {th }}$ TCRC, Washington, DC, 1983, No. 8.

367. Melikian, A.A., E.J. LaVoie, S.S. Hecht, and D. Hoffmann: 5-Methylchrysene metabolism in mouse epidermis in vivo, diol epoxide-DNA adduct persistence, and diol epoxide reactivity with DNA as potential factors influencing the predominance of 5-methylchrysene-1,2-diol-3,4-epoxideDNA adducts in mouse epidermis; Carcinogenesis 4 (1983) 843-849.

368. Melikian, A.A., E.J. LaVoie, S.S. Hecht, and D. Hoffmann: On the enhancing effect of a bay-region methyl group in 5methylchrysene carcinogenesis; in: Polynuclear Aromatic Hydrocarbons Formation, Metabolism and Measurements; edited by M. Cooke and A.J. Dennis, Battelle Press, Columbus, OH, 1983, pp. 861-875.

369. Rice, J.E., V. Bedenko, E.J. LaVoie, and D. Hoffmann: Studies on the metabolism of fluoranthene, 2-methylfluoranthene, and 3-methylfluoranthene; in: Polynuclear Aromatic Hydrocarbons - Formation, Metabolism and Measurements; edited by M. Cooke and A.J. Dennis, Battelle Press, Columbus, OH, 1983, pp. 1009-1020.

370. Rice, J.E., E.J. LaVoie, and D. Hoffmann: Synthesis of the isomeric phenols and trans-2,3-dihydrodiol of fluoranthene; J. Org. Chem. 48 (1983) 2360-2363.

371. Rivenson, A., K. Furuya, S.S. Hecht, and D. Hoffmann: Experimental nasal cavity tumors induced by tobaccospecific nitrosamines (TSNA); in: Nasal Tumor in Animals and Man, Vol. 3: edited by G. Reznik and S.F. Stinson, CRC Press Inc., Boca Raton, FL, 1983, pp. 79-113.

372. Shigematsu, A., J.D. Adams, J. Camanzo, E.J. LaVoie, and D. Hoffmann: Steam-volatile components in the tobacco and mainstream smoke of cigarettes with low 'tar' yields; presented at the $37^{\text {th }}$ TCRC, Washington, DC, 1983, No. 12 .

373. Tso, T.C., J.D. Adams, N.J. Haley, and D. Hoffmann: The smokers' dependence on nicotine and the fate of nicotine during tobacco curing and smoking, and its reduction; in: Proc. $5^{\text {th }}$ World Conf. on Smoking and Health, Winnipeg, Canada, 1983, pp. 229-238.

374. Wenke, G. and D. Hoffmann: A study of betel quid carcinogenesis. 1 . On the in vitro $N$-nitrosation of arecoline; Carcinogenesis 4 (1983) 169-172.

375. Adams, J.D., E.J. LaVoie, M. O’Donnell, and D. Hoffmann:
On the pharmacokinetics of tobacco-specific $N$-nitrosamines; in: $N$-Nitroso Compounds: Occurrence, Biological Effects and Relevance to Human Cancer, IARC Sci. Publ. 57 (1984) 779-785.

376. Adams, J.D., S.J. Lee, and D. Hoffmann: [Chemical Studies on Tobacco Smoke. LXXVIII.] Carcinogenic agents in cigarette smoke and the influence of nitrate on their formation; Carcinogenesis 5 (1984) 221-223.

377. Adams, J.D., P. Owens-Tucciarone, and D. Hoffmann: Tobacco carcinogenesis and asbestos fibers: a model study; presented at the $75^{\text {th }}$ Ann. Meeting Am. Assoc. Cancer Res., Toronto, Canada, 1984.

378. Brunnemann, K.D., S.J. Lee, S. Adams, and D. Hoffmann: Occurrence of $N$-nitrosamines in chewing tobacco: a closer look; presented at the $38^{\text {th }}$ TCRC, Atlanta, GA, 1984, No. 26.

379. Brunnemann, K.D., J.C. Scott, N.J. Haley, and D. Hoffmann: Endogenous formation of $N$-nitrosoproline upon cigarette smoke inhalation; in: $N$-Nitroso Compounds: Occurrence, Biological Effects and Relevance to Human Cancer, IARC Sci. Publ. 57 (1984) 819-828.

380. Brunnemann, K.D., J.C. Scott, and D. Hoffmann: Development of an HPLC postcolumn photolysis detector for the determination of $\mathrm{N}$-nitrosamides; presented at the $\mathrm{CO}$ RESTA Congress Vienna, Austria, 1984, No. S11.

381. Carmella, S.G., S.S. Hecht, T.C. Tso, and D. Hoffmann: [Chemical Studies on Tobacco Smoke. LXXVII.] Roles of tobacco cellulose, sugars, and chlorogenic acid as precursors to catechol in cigarette smoke; J. Agric. Food Chem. 32 (1984) 267-273.

382. El-Bayoumi, K., M. O'Donnell, S.S. Hecht, and D. Hoffmann: The influence of tobacco nitrate on aromatic amines and nitro-aromatics in cigarette smoke; presented at the $38^{\text {th }}$ TCRC, 1984, Atlanta, GA, No. 36.

383. Hecht, S.S., A. Castonguay, F.-L. Chung, and D. Hoffmann: Carcinogenicity and metabolism activation of tobaccospecific nitrosamines: current status and future prospects; in: $\mathrm{N}$-Nitroso Compounds: Occurrence, Biological Effects and Relevance to Human Cancer, IARC Sci. Publ. 57 (1984) 763-778.

384. Hoffmann, D., K.D. Brunnemann, and J.D. Adams: Tobacco-specific $N$-nitrosamines (TSNA): recent progress on occurrence, formation and reduction; presented at the CORESTA Congress Vienna, Austria, 1984, No. S15.

385. Hoffmann, D., K.D. Brunnemann, J.D. Adams, and N.J. Haley: Indoor air pollution by tobacco smoke: model studies on the uptake by nonsmokers; in: Indoor Air. Radon, Passive Smoking, Particulates and Housing Epidemiology. Proc. $3^{\text {rd }}$ Internatl. Conf. on Indoor Air Quality and Climate Stockholm, Sweden, Vol. 2, D 17, 1984, pp. 313-318.

386. Hoffmann, D., K.D. Brunnemann, J.D. Adams, and S.S. Hecht: Formation and analysis of $N$-nitrosamines in tobacco products and their endogenous formation in tobacco consumers; in: $N$-Nitroso Compounds: Occurrence, Biological Effects and Relevance to Human Cancer, IARC Sci. Publ. 57 (1984) 743-762.

387. Hoffmann, D., N.J. Haley, J.D. Adams, and K.D. Brunnemann: Tobacco Sidestream Smoke: Uptake by Nonsmokers; Prev. Med. 13 (1984) 608-617.

388. Hoffmann, D., A. Rivenson, S. Amin, and S.S. Hecht: [A Study of Tobacco Carcinogenesis. XXVII.] Dose-Response Study on the Carcinogenicity of Tobacco-Specific NNitrosamines in F344 rats; J. Cancer Res. Clin. Oncol. 108 (1984) 81-86.

389. LaVoie, E.J., A. Shigematsu, E.A. Adams, J. Rigotty, and D. Hoffmann: Tumor-initiating activity of quinoline and methylated quinolines on the skin of SENCAR mice; Cancer Lett. 22 (1984) 269-273.

390. Melikian, A.A., S. Amin, S.S. Hecht, D. Hoffmann, J. 
Pataki, and R.G. Harvey: Identification of the major adducts formed by reaction of 5-methylchrysene anti-dihydrodiol epoxides with DNA in vitro; Cancer Res. 44 (1984) 2524-2529.

391. Sasson, I.M., D.T. Coleman, E.J. LaVoie, D. Hoffmann, and E.L. Wynder: Influence of diet and smoking on the mutagenic activity of human urine: vegan diet increases mutagenicity; presented at the $75^{\text {th }}$ Ann. Meeting Am. Assoc. Cancer Res., Toronto, Canada, 1984, No. 102.

392. Wenke, G., K.D. Brunnemann, D. Hoffmann, and S.V. Bhide: A Study of Betel Quid Carcinogenesis. 4. Analysis of the saliva of betel chewers. A preliminary report; J. Cancer Res. Clin. Oncol. 108 (1984) 110-113.

393. Wenke, G., A. Rivenson, K.D. Brunnemann, and D. Hoffmann: A Study of Betel Quid Carcinogenesis. 2. On the formation of $N$-nitrosamines during betel quid chewing; in: $N$-Nitroso Compounds: Occurrence, Biological Effects and Relevance to Human Cancer, IARC Sci. Publ. 57 (1984) 859-866.

394. Wenke, G., A. Rivenson, and D. Hoffmann: A Study of Betel Quid Carcinogenesis. 3. 3-(Methylnitrosamino)propionitrile, a powerful carcinogen in F344 rats; Carcinogenesis 5 (1984) 1137-1140.

395. Wynder, E.L., M.T. Goodman, and D. Hoffmann: Demographic aspects of the low-yield cigarette; J. Natl. Cancer Inst. 72 (1984) 817-822.

396. Adams, J.D., E.J. LaVoie, and D. Hoffmann: [A Study of Tobacco Carcinogenesis. XXVIII.] On the pharmacokinetics of tobacco-specific $\mathrm{N}$-nitrosamines in Fischer rats; Carcinogenesis 6 (1985) 509-511.

397. Adams, J.D., E.J. LaVoie, K.J. O’Mara-Adams, D. Hoffmann, K.D. Carey, and M.V. Marshall: [A Study of Tobacco Carcinogenesis. XXIX.] Pharmacokinetics of $N$ '-nitrosonornicotine and 4-(methylnitrosamino)-1-(3-pyridyl)-1-butanone in laboratory animals; Cancer Lett. 28 (1985) 195-201.

398. Adams, J.D., K.J. O'Mara-Adams, and D. Hoffmann: On the mainstream-sidestream distribution of smoke components from commercial cigarettes; presented at the $39^{\text {th }} \mathrm{TCRC}$, Montreal, Canada, 1985, No. 34.

399. Bache, C.A., D.J. Lisk, G.J. Doss, D. Hoffmann, and J.D. Adams: Cadmium and nickel in mainstream particulates of cigarettes containing tobacco grown on a low cadmium soilsludge mixture; J. Environ. Toxicol. 16 (1985) 547-552.

400. Brunnemann, K.D., L. Genoble, and D. Hoffmann: [Chemical Studies on Tobacco Smoke. LXXXIV.] $N$-Nitrosamines in chewing tobacco: an international comparison; J. Agr. Food Chem. 33 (1985) 1178-1181.

401. Chou, D., K.D. Brunneman, J.D. Adams, and D. Hoffmann: On the isolation and identification of new tobacco-specific $N$-nitrosamines; presented at the $39^{\text {th }}$ TCRC, Montreal, Canada, 1985, No. 22.

402. El-Bayoumy, K., M. O’Donnell, S.S. Hecht, and D. Hoffmann: [Chemical Studies on Tobacco Smoke. LXXXII.] On the analysis of 1-nitronaphthalene, 1-nitropyrene, and 6nitrochrysene in cigarette smoke; Carcinogenesis 6 (1985) 505-507.

403. Haley, N.J. and D. Hoffmann: Analysis for nicotine and cotinine in hair to determine cigarette smoker status; Clin. Chem. 31 (1985) 1598-1600.

404. Haley, N.J., D.W. Sepkovic, D. Hoffmann, and E.L. Wynder: Cigarette smoking as a risk for cardiovascular disease. Part VI. Compensation with nicotine availability as a single variable; Clin. Pharmacol. Ther. 38 (1985) 164-170.

405. Hecht, S.S., A. Amin, A.A. Melikian, E.J. LaVoie, and D. Hoffmann: Effects of methyl and fluorine substitution on the metabolic activation and tumorigenicity of polycyclic aromatic hydrocarbons; Amer. Chem. Soc. Symp. Series 238 (1985) 85-105

406. Hecht, S.S., L. Radok, S. Amin, K. Huie, A.A. Melikian, D.
Hoffmann, J. Pataki, and R.G. Harvey: Tumorigenicity of 5methylchrysene dihydrodiols and dihydrodiol epoxides in newborn mice and on mouse skin; Cancer Res. 45 (1985) 1449-1452.

407. Hoffmann, D. and S.S. Hecht: [A Study of Tobacco Carcinogenesis. XXX.] Perspectives in Cancer Research. Nicotine-derived $N$-nitrosamines and tobacco-related cancer: current status and future directions; Cancer Res. 45 (1985) 935-944.

408. Hoffmann, D., S.S. Hecht, N.J. Haley, K.D. Brunnemann, J.D. Adams, and E.L. Wynder: Tumorigenic agents in tobacco products and their uptake by chewers, smokers and nonsmokers; J. Cell. Biochem. Suppl. 9C (1985) 33.

409. Hoffmann, D., E.J. LaVoie, and S.S. Hecht: Nicotine: a precursor for carcinogens. Cancer Lett. 26 (1985) 67-75.

410. Hoffmann, D., A. Melikian, J.D. Adams, K.D. Brunnemann, and N.J. Haley: New Aspects of Tobacco Carcinogenesis; in: Carcinogenesis; edited by M.J. Maas et al., Raven Press, New York, NY, 1985, pp. 239-256.

411. Hoffmann, D., A.S. Rivenson, and S.S. Hecht: The Role of Nicotine in Tobacco Carcinogenesis; in: Hommage au Professeur Rene Truhaut; edited by Comité d'organisation du jubilé scientifique du Prof. R. Truhaut, Tardy Quercy (S.A.), Cahors, France, 1985, pp. 491-495.

412. Hoffmann, D. and E.L. Wynder: The selective reduction of cigarette smoke constituents. Proc. $1^{\text {st }}$ Member Congress China Tobacco Soc., Beijing, China, 1985, pp. 234-279.

413. LaVoie, E.J., E.A. Adams, A. Shigematsu, and D. Hoffmann: Metabolites of phenanthridine formed by rat liver homogenate; Drug Metab. Dispos. 13 (1985) 71-75.

414. LaVoie, E.J., D.T. Coleman, J.E. Rice, N.G. Geddie, and D. Hoffmann: Tumor-initiating activity, mutagenicity, and metabolism of methylated anthracenes; Carcinogenesis 6 (1985) 1483-1488.

415. LaVoie, E.J., A. Shigematsu, B. Mu, A. Rivenson, and D. Hoffmann: The effects of catechol on the urinary bladder of rats treated with $N$-butyl- $N$-(4-hydroxybutyl)nitrosamine; Gann: Jpn. J. Cancer Res. 76 (1985) 266-271.

416. LaVoie, E.J., A. Shigematsu, A. Rivenson, B. Mu, and D. Hoffmann: Evaluation of the effects of cotinine and nicotine- $N$ '-oxides on the development of tumors in rats initiated with $N$-[4-(5-nitro-2-furyl)-2-thiazolyl]-formamide; J. Natl. Cancer Inst. 75 (1985) 1075-1081.

417. LaVoie, E.J., A. Shigematsu, P.L. Tucciarone, J.D. Adams, and D. Hoffmann: [Chemical Studies on Tobacco Smoke. LXXXIII.] Comparison of the steam-volatile components of commercial cigarette, pipe, and chewing tobaccos; J. Agric. Food Chem. 33 (1985) 876-879.

418. Melikian, A.A., S.S. Hecht, D. Hoffmann, J. Pataki, and R.G. Harvey: Analysis of syn- and anti-1,2-dihydroxy-3,4epoxy-1,2,3,4-tetrahydro-5-methylchrysene-deoxyribonucleoside adducts by boronate chromatography; Cancer Lett. 27 (1985) 91-97.

419. Melikian, A.A., J.M. Leszczynska, S. Amin, S.S. Hecht, D. Hoffmann, J. Pataki, and R.G. Harvey: Rates of hydrolysis and extents of DNA-binding of 5-methylchrysene dihydrodiol epoxides; Cancer Res. 45 (1985) 1990-1996.

420. Sasson, I.M., D.T. Coleman, E.J. LaVoie, D. Hoffmann, and E.L. Wynder: Mutagens in human urine: Effects of cigarette smoking and diet; Mutat. Res. 158 (1985) 149-157.

421. Sasson, I.M., N.J. Haley, D. Hoffmann, E.L. Wynder, D. Hellberg, and S. Nilsson: Cigarette Smoking and Neoplasia of the Uterine Cervix: Smoke Constituents in Cervical Mucus; N. Engl. J. Med. 312 (1985) 315-316.

422. Wynder, E.L., M.T. Goodman, and D. Hoffmann: Lung Cancer Etiology: Challenges of the Future; in: Cancer of the Respiratory Tract: Predisposing Factors; edited by M.J. Maas et al., Raven Press, New York, NY, 1985, pp. 39-62.

423. Zaridze, D.G., M. Blettner, N.N. Trapeznikov, J.P. Kuvshi- 
nov, E.G. Matiakin, B.P. Poljakov, B.K. Poddubni, S.M. Parshikova, V.I. Rottenberg, F.S. Chamrakulov, M.C. Chodjaeva, H.F. Stich, M.P. Rosin, D.I. Thurnham, D. Hoffmann, and K.D. Brunnemann: Survey of a population with a high incidence of oral and esophageal cancer; Int. J. Cancer 36 (1985) 153-158.

424. Adams, J.D., P.L. Tucciarone, L. Genoble, K.D. Brunnemann, and D. Hoffmann: On the anaylsis of $N$-nitroso compounds in tobacco and tobacco smoke by capillary GCTEA; presented at the $40^{\text {th }}$ TCRC, Knoxville, TN, No. 48.

425. Bache, C.A., C.M. Reid, D. Hoffmann, J.D. Adams, and D.J. Lisk: Cadmium in smoke particulates of regular and filter cigarettes containing low and high cadmium concentrations; Bull. Environ. Contam. Toxicol. 36 (1986) 372-375.

426. Brunnemann, K.D., B. Prokopczyk, D. Hoffmann, J. Nair, H. Ohshima, and H. Bartsch: Laboratory studies on oral cancer and smokeless tobacco; in: Mechanisms in Tobacco Carcinogenesis, Banbury Report, No. 23; edited by D. Hoffmann and C.C. Harris, Cold Spring Harbor Laboratory, Cold Spring Harbor, NY, 1986, pp. 197-213.

427. Brunnemann, K.D., R. Onrust, and D. Hoffmann: Determination of volatile carbonyl compounds in tobacco headspace and tobacco smoke; presented at the $40^{\text {th }}$ TCRC, Knoxville, 1986, No. 47.

428. Connolly, G.N., D.M. Winn, S.S. Hecht, J.E. Henningfield, B. Walker Jr, and D. Hoffmann: The reemergence of smokeless tobacco; N. Engl. J. Med. 314 (1986) 1020-1027.

429. Donahue, J.M., K. El-Bayoumi, S.S. Hecht, and D. Hoffmann: Aromatic amines in human urine; presented at the $77^{\text {th }}$ Ann. Meeting Am. Assoc. Cancer Res., 1986, No. 373.

430. El-Bayoumy, K., J.M. Donahue, S.S. Hecht, and D. Hoffmann: Analysis of aniline and $o$-toluidine in human urine; in: Mechanisms in Tobacco Carcinogenesis, Banbury Report, No. 23; edited by D. Hoffmann and C.C. Harris, Cold Spring Harbor Laboratory, Cold Spring Harbor, NY, 1986, pp. 77-84.

431. El-Bayoumy, K., J.M. Donahue, S.S. Hecht, and D. Hoffmann: [A Study of Tobacco Carcinogenesis. XXXIII.] Identification and quantitative analysis of aniline and toluidines in human urine; Cancer Res. 46 (1986) 6064-6067.

432. Haley, N.J., D. Hoffmann, and E.L. Wynder: Uptake of Tobacco Smoke Components; in: Mechanisms in Tobacco Carcinogenesis, Banbury Report, No. 23; edited by D. Hoffmann and C.C. Harris, Cold Spring Harbor Laboratory, Cold Spring Harbor, NY, 1986, pp. 3-19.

433. Hecht, S.S., P.G. Foiles, S.G. Carmella, N. Trushin, A. Rivenson, and D. Hoffmann: Recent studies on the metabolic activation of tobacco-specific nitrosamines: Prospects for dosimetry in humans; in: Mechanisms in Tobacco Carcinogenesis, Banbury Report, No. 23; edited by D. Hoffmann and C.C. Harris, Cold Spring Harbor Laboratory, Cold Spring Harbor, NY, 1986, pp. 245-257.

434. Hecht, S.S., A. Rivenson, J. Braley, J. DiBello, J.D. Adams, and D. Hoffmann: [A Study of Tobacco Carcinogenesis. XXXII.] Induction of oral cavity tumors in F344 rats by tobacco-specific nitrosamines and snuff; Cancer Res. 46 (1986) 4162-4166.

435. Hoffmann, D., K.D. Brunnemann, J.D. Adams, and S.S. Hecht: Laboratory studies on snuff-dipping and oral cancer; Cancer J. 1 (1986) 10-13.

436. Hoffmann, D., N.H. Harley, I. Fisenne, J.D. Adams, and K.D. Brunnemann: [A Study of Tobacco Carcinogenesis. XXXI.] Carcinogenic agents in snuff; J. Natl. Cancer Inst. 76 (1986) 435-437.

437. Hoffmann, D. and C.C.Harris: Mechanisms in tobacco carcinogenesis; Banbury Report, No. 23; edited by D. Hoffmann and C.C. Harris, Cold Spring Harbor Laboratory, Cold Spring Harbor, NY, 1986, pp. 428.

438. Hoffmann, D., S.S. Hecht, A.A. Melikian, N.J. Haley, K.D.
Brunnemann, J.D. Adams, and E.L. Wynder: Tumorigenic agents in tobacco products and their uptake by chewers, smokers and nonsmokers; in: Biochemical and Molecular Epidemiology of Cancer; edited by C.C. Harris, Alan Liss Inc., New York, NY, 1986, pp. 191-204.

439. Hoffmann, D. and E.L. Wynder: The tumor initiator in tobacco smoke; Proc. Am. Assoc. Cancer Res. , Chicago, 7 (1986) 32.

440. Hoffmann, D. and E.L. Wynder: [A Study of Tobacco Carcinogenesis. XXXVII.] Chemical constituents and bioactivity of tobacco smoke; in: Tobacco - A Major International Health Hazard, IARC Sci. Publ. 74 (1986) 145-165.

441. Kuller, L.H., L. Garfinkel, P. Correa, N. Haley, D. Hoffmann, S. Preston-Martin, and D. Sandler: Contribution of passive smoking to respiratory cancer; Environ. Health Perspect. 70 (1986) 57-69.

442. LaVoie, E.J., J.D. Adams, J. Reinhardt, A. Rivenson, and D. Hoffmann: Toxicity studies on clove cigarette smoke and constituents of clove: determination of the $\mathrm{LD}_{50}$ of eugenol by intratracheal instillation in rats and hamsters; Arch. Toxicol. 59 (1986) 78-81.

443. LaVoie, E.J., J.D. Adams, J. Reinhardt, A. Rivenson, and D. Hoffmann: Comments on the toxicology of constituents in clove cigarette smoke; Arch. Toxicol. 59 (1986) 298-299.

444. LaVoie, E.J., I.M. Sasson, D. Hoffmann, M.V. Marshall, and W. Rodgers: Mutagens in the urine of cigarette smokers; in: Mechanisms of Tobacco Carcinogenesis, Banbury Report 23; edited by D. Hoffmann and C.C. Harris, 1986, pp. 121-136.

445. Melikian, A.A., J.M. Leszczynska, S.S. Hecht, and D. Hoffmann: Effects of the co-carcinogen catechol on benzo $[a]$ pyrene metabolism and DNA adduct formation in mouse skin; Carcinogenesis 7 (1986) 9-15.

446. Palladino, G., J.D. Adams, K.D. Brunnemann, N.J. Haley, and D. Hoffmann: [A Study of Tobacco Carcinogenesis. XXXVI.] Snuff-dipping in college students: a clinical profile; Mil. Med. 151 (1986) 342-346.

447. Parsa, I., C.A. Foye, C.M. Cleary, and D. Hoffmann: Differences in metabolism and biological effects of NNK in human target cells; in: Mechanisms of Tobacco Carcinogenesis, Banbury Report, No. 23; edited by D. Hoffmann and C.C. Harris, Cold Spring Harbor Laboratory, Cold Spring Harbor, NY, 1986, pp. 233-244.

448. Rivenson, A., D. Hoffmann, and S.S. Hecht: Local and regional tumors induced by smokeless tobacco and its components in Fischer rats; $14^{\text {th }}$ Int. Cancer Cong., Budapest, Hungary (1986).

449. Sepkovic, D.W., N.J. Haley, and D. Hoffmann: Elimination from the body of tobacco products by smokers and passive smokers; J. Am. Med. Assoc. 256 (1986) 863.

450. Zaridze, D.G., M. Blettner, E.G. Matiakin, B.P. Poljakov, H.F. Stich, M.P. Rosin, D. Hoffmann, and K.D. Brunnemann: The effect of nass use and smoking on the risk of oral leukoplakia; Cancer Detect. Prevent. 9 (1986) 435-440.

451. Abbaspour, A., S.S. Hecht, and D. Hoffmann: [Chemical Studies on Tobacco Smoke. LXXXVII.] Synthesis of 5'carboxy- $N$ '-nitrosonornicotine and $5{ }^{\prime}-\left[{ }^{14} \mathrm{C}\right]$ carboxy- $N$ 'nitrosonornicotine; J. Org. Chem. 52 (1987) 3474-3477.

452. Adams, J.D., K.J. O'Mara-Adams, and D. Hoffmann: [Chemical Studies on Tobacco Smoke. LXXXVI.] Toxic and carcinogenic agents in undiluted mainstream smoke and sidestream smoke of different types of cigarettes; Carcinogenesis 8 (1987) 729-731.

453. Adams, J.D., P. Owens-Tucciarone, and D. Hoffmann: Tobacco-specific $N$-nitrosamines in dry snuff; Food Chem. Toxicol. 25 (1987) 245-246.

454. Bache, C.A., D.J. Lisk, B.S. Shane, D. Hoffmann, and J.D. Adams: Effectiveness of cigarette filter tips for reducing cadmium in relation to other mainstream smoke constitu- 
ents; Drug Chem. Toxicol. 10 (1987) 189-193.

455. Brunnemann, K.D., L. Genoble, and D. Hoffmann: [Chemical Studies on Tobacco Smoke. LXXXV.] Identification and analysis of a new tobacco-specific $N$-nitrosamine, 4(methylnitrosamino)-4-(3-pyridyl)-1-butanol; Carcinogenesis 8 (1987) 465-469.

456. Brunnemann, K.D., N.J. Haley, J.D. Adams, D.W. Sepkovic, and D. Hoffmann: Model studies on the uptake of nicotine after exposure to environmental tobacco smoke (ETS); presented at the $41^{\text {st }}$ TCRC, NC, 1987, No. 31 .

457. Brunnemann, K.D., A. Rivenson, J.D. Adams, S.S. Hecht, and D. Hoffmann: A study of snuff carcinogenesis; in: The Relevance of $N$-Nitroso Compounds to Human Cancer: Exposures and Mechanisms, IARC Sci. Publ. 84 (1987) 456-459.

458. El-Bayoumy, K., M. O’Donnell, and D. Hoffmann: Determination of aromatic amines in sidestream smoke; in: Environmental Carcinogens: Methods of Analysis and Exposure Measurement, IARC Sci. Publ. 81 (1987) 269-277.

459. Gutenmann, W.H., D.J. Lisk, B.S. Shane, D. Hoffmann, and J.D. Adams: Selenium in mainstream and sidestream smoke of cigarettes containing fly ash-grown tobacco; Drug Chem. Toxicol. 10 (1987) 181-187.

460. Haley, N.J., J.D. Adams, J. Alzofon, and D. Hoffmann: Uptake of sidestream smoke by Syrian golden hamsters; Toxicol. Lett. 35 (1987) 83-88.

461. Haley, N.J., J.D. Adams, C.M. Axelrad, and D. Hoffmann: Sidestream smoke uptake by Syrian golden hamsters in an inhalation bioassay; in: Proc. $4^{\text {th }}$ International Conf. Indoor Air '87, Berlin, Germany, Vol. 2 (Environmental tobacco smoke, multicomponent studies, radon, sick buildings, odors and irritants, hyperreactivities and allergies; edited by B. Seifert et al., Institute for Water, Soil and Air Hygiene) 1987, pp. 68-73.

462. Hoffmann, D., J.D. Adams, and K.D. Brunnemann: A critical look at $N$-nitrosamines in environmental tobacco smoke; Toxicol. Lett. 35 (1987) 1-8.

463. Hoffmann, D., J.D. Adams, D. Lisk, I. Fisenne, and K.D. Brunnemann: [A Study of Tobacco Carcinogenesis. XXXIX.] Toxic and carcinogenic agents in dry and moist snuff; J. Natl. Cancer Inst. 79 (1987) 1281-1286.

464. Hoffmann, D., K.D. Brunnemann, N.J. Haley, D.W. Sepkovic, and J.D. Adams: Nicotine uptake by nonsmokers exposed to passive smoking under controlled conditions and the elimination of cotinine; in: Proc. $4^{\text {th }}$ International Conf. Indoor Air '87, Berlin, Germany, Vol. 2, (Environmental tobacco smoke, multicomponent studies, radon, sick buildings, odors and irritants, hyperreactivities and allergies; edited by B. Seifert et al., Institute for Water, Soil and Air Hygiene), 1987, pp. 13-17.

465. Hoffmann, D. and I. Hoffmann: Significance of Exposure to Sidestream Tobacco Smoke; in: Environmental Carcinogens - Methods of Analysis and Exposure Measurement. Vol. 9: Passive Smoking, IARC Sci. Publ. 81 (1987) 3-10.

466. Hoffmann, D., E.J. LaVoie, and S.S. Hecht: Chemical fractionation and bioassay of complex mixtures: studies in tobacco carcinogenesis; in: Health and Environmental Research on Complex Organic Mixtures; edited by R.H. Gray et al., Battelle, Pacific Northwest Laboratory, Richland, WA, 1987, pp. 151-165.

467. Hoffmann, D., E.L. Wynder, S.S. Hecht, K.D. Brunnemann, E.J. LaVoie, and N.J. Haley: Chemical carcinogens in tobacco; in: Cancer Risks: Strategies for Elimination; edited by P. Bannasch, Springer-Verlag, Berlin, 1987, pp. 101-113.

468. Prokopczyk, G., J.D. Adams, E.J. LaVoie, and D. Hoffmann: [A Study of Tobacco Carcinogenesis. XXXIV.] Effect of snuff and nicotine on DNA methylation by 4(methylnitrosamino)-1-(3-pyridyl)-1-butanone; Carcinogenesis 8 (1987) 1395-1397.
469. Prokopczyk, B., K.D. Brunnemann, P. Bertinato, and D. Hoffmann:The role of $N$-(nitrosomethylamino)propionitrile in betel-quid carcinogenesis; IARC Monogr. 84 (1987) 470-473.

470. Prokopczyk, B., A. Rivenson, P. Bertinato, K.D. Brunnemann, and D. Hoffmann: [A study of betel quid carcinogenesis. V.] 3-(Methylnitrosamino)propionitrile: occurrence in saliva of betel quid chewers, carcinogenicity and DNA methylation in F344 rats; Cancer Res. 47 (1987) 467-471.

471. Schiffmann, M.H., N.J. Haley, J.S. Felton, A.W. Andrews, R.A. Kaslow, W.D. Lancaster, R.J. Kurman, L.A. Brinton, L.B. Lannom, and D. Hoffmann: Biochemical epidemiology of cervical neoplasia: measuring cigarette smoke constituents in the cervix; Cancer Res. 47 (1987) 3886-3888.

472. Tucciarone, P.L., J.D. Adams, E.L. LaVoie, M. Kagan, and D. Hoffmann: Quantitative analyses of steam distillates and aqueous extracts of commercial smokeless tobaccos; presented at the $41^{\text {st }}$ TCRC, 1987, Greensboro, NC, No. 11.

473. Brunnemann, K.D., M.R. Kagan, and D. Hoffmann: Analysis of selected gas phase components by GC-MSD; presented at the $42^{\text {nd }}$ TCRC, Lexington, KY, 1988, No. 18.

474. Brunnemann, K.D., A. Rivenson, A. Czech, E.J. LaVoie, and D. Hoffmann: Isolation, identification, and bioassay of the tobacco-specific $N$-nitrosamine 4-methylnitrosamino-(3pyridyl)-1-butanol; Proc. Am. Assoc. Cancer Res. 29 (1988) No. 332.

475. Djordjevic, M.V., K.D. Brunnemann, and D. Hoffmann: Identification and analysis of nicotine-derived $N$-nitrosamino acid and other nitrosamino acids in tobacco; presented at the $42^{\text {nd }}$ TCRC, Lexington, KY, 1988, No. 41.

476. Haley, N.J., D.W. Sepkovic, E. Louis, and D. Hoffmann: Absorption and elimination by smokers, nonsmokers, and chewers of nicotine gum; in: The Pharmacology of Nicotine; edited by M.J. Rand and K. Thurau, IRL Press, Washington, DC, 1988, pp. 20-21.

477. Hecht, S.S., A. Abbaspour, and D. Hoffmann: A Study of Tobacco Carcinogenesis. XLII. Bioassay in A/J mice of some structural analogues of tobacco-specific nitrosamines; Cancer Lett. 42 (1988) 141-145.

478. Hecht, S.S., S.G. Carmella, N. Trushin, T.E. Spratt, P.G. Foiles, and D. Hoffmann: Approaches to the development of assays for interaction of tobacco specific nitrosamines with hemoglobin and DNA; in: Methods for Detecting DNA Damaging Agents in Humans: Applications in Cancer Epidemiology and Prevention, IARC Sci. Publ. 89 (1988) 121-128.

479. Hecht, S.S. and D. Hoffmann: Tobacco-specific nitrosamines, an important group of carcinogens in tobacco and tobacco smoke; Carcinogenesis 9 (1988) 875-884.

480. Hellberg, D., S. Nilsson, N.J. Haley, D. Hoffmann, and E. Wynder: Smoking and cervical intraepithelial neoplasia nicotine and continine in serum and cervical mucus in smokers and nonsmokers; Am. J. Obstet. Gynecol. 158 (1988) 910-913.

481. Hoffmann, D.: Krank durch Passivrauchen? Oral presentation held on the Symposium 'Krank durch Passivrauchen?' Vienna, Austria, 1988, in: Transcription of a live recording, pp. 41-45.

482. Hoffmann, D., J.D. Adams, E.J. LaVoie, and S.S. Hecht: Biochemistry, pharmacokinetics and carcinogenicity of nicotine-derived nitrosamines; in: Pharmacology of Nicotine; edited by M.J. Rand and K. Thurau, IRL Press, Oxford, UK, 1988, pp. 43-60.

483. Hoffmann, D., K.D. Brunnemann, and S. Venitt: Carcinogenic nitrosamines in oral snuff; Lancet 331 (1988) 1232.

484. Hoffmann, D. and S.S. Hecht: Smokeless tobacco and cancer; ISI Atlas of Science. Pharmacology 2 (1988) 46-52.

485. Prokopczyk, B., P. Bertinato, and D. Hoffmann: Cyanoethylation of DNA in vivo by 3-(methylnitrosamino)proprio- 
nitrile, an areca-derived carcinogen; Cancer Res. 48 (1988) 6780-6784.

486. Prokopczyk, B., P. Bertinato, and D. Hoffmann: Synthesis and kinetics of decomposition of 7-(2-cyanoethyl)guanine and $\mathrm{O}^{6}$-(2-cyanoethyl)guanine, markers for reaction of acrylonitrile and 3-(methylnitrosamino)propionitrile with DNA; Carcinogenesis 9 (1988) 2125-2128.

487. Rivenson, A., S.S. Hecht, and D. Hoffmann: Observations on lung tumors arising from metaplastic squamous epithelium in rats treated chronically with the tobacco-specific $N$ nitrosamine 4-methylnitrosamino-1-(3-pyridyl)-1-butanone (NNK); Proc. Am. Assoc. Cancer Res. 29 (1988) No. 342.

488. Rivenson, A., D. Hoffmann, B. Prokopczyk, S. Amin, and S.S. Hecht: [A Study of Tobacco Carcinogenesis. XLI.] Induction of lung and exocrine pancreas tumors in F344 rats by tobacco-specific and areca-derived $N$-nitrosamines; Cancer Res. 48 (1988) 6912-6917.

489. Sepkovic, D.W., N.J. Haley, and D. Hoffmann: Use of Urinary Cotinine to Estimate Exposure to Tobacco Smoke Reply; JAMA 259 (1988) 1808-1809.

490. Anderson, L.M., S.S. Hecht, D.E. Dixon, L.F. Dove, R.M. Kovatch, S. Amin, D. Hoffmann, and J.M. Rice: Evaluation of the transplacental tumorigenicity of the tobacco-specific carcinogen 4-(methylnitrosamino)-1-(3-pyridyl)-1-butanone in mice; Cancer Res. 49 (1989) 3770-3775.

491. Brunnemann, K.D., R. Feng, and D. Hoffmann: Pyrolysis studies of selected nitrosamino acids in cigarettes; presented at the $43^{\text {rd }}$ TCRC, Richmond, VA, 1989, No. 44.

492. Brunnemann, K.D., M.R. Kagan, J.E. Cox, and D. Hoffmann: [Chemical Studies on Tobacco Smoke. LXXXVII.] Determination of benzene, toluene and 1,3-butadiene in cigarette smoke by GC-MSD; Exp. Pathol. 37 (1989) 108-113.

493. Djordjevic, M.V., C.W. Sigountos, K.D. Brunnemann, and D. Hoffmann: On the formation of 4-(methylnitrosamino)-4(3-pyridyl) butyric acid in tobacco and tobacco smoke; presented at the $43^{\text {rd }}$ TCRC, Richmond, VA, 1989, No. 27.

494. Djordjevic, M.V., K.D. Brunnemann, and D. Hoffmann: [A Study of Tobacco Carcinogenesis. XLIII.] Identification and analysis of a nicotine-derived $N$-nitrosamino acid and other nitrosamino acids in tobacco; Carcinogenesis 10 (1989) 1725-1731.

495. Haley, N.J., D.W. Sepkovic, K.D. Brunnemann, and D. Hoffmann: Biomarkers for Assessing Environmental Tobacco Smoke Update; in: Combustion Processes and the Quality of the Indoor Environment; edited by J. P. Harper, Air and Waste Management Association, Pittsburgh, PA, 1989, pp, 1-13.

496. Haley, N.J., D.W. Sepkovic, and D. Hoffmann: Elimination of cotinine from body fluids: disposition in smokers and nonsmokers; Am. J. Public Health 79 (1989) 1046-1048.

497. Hecht, S.S. and D. Hoffmann: The relevance of tobaccospecific nitrosamines to human cancer; Cancer Surv. 8 (1989) 273-294.

498. Hoffmann, D.: Nicotine - a tobacco-specific precursor for carcinogens; in: Nicotine, Smoking, and the Low-Tar Programme; edited by N. Wald and P. Frogatt, Oxford University Press, Oxford, UK, 1989, pp. 24-40.

499. Hoffmann, D., K.D. Brunnemann, and I. Hoffmann: Significance of Benzene in Tobacco Carcinogenesis; in: Benzene: Occupational and Environmental Hazards - Scientific Update; edited by M.A. Mehlman, Princeton Scientific Publ. Co., Princeton, NY, 1989, pp. 99-112.

500. Hoffmann, D. and S.S. Hecht: Advances in Tobacco Carcinogenesis; in: Chemical Carcinogenesis and Mutagenesis, Springer Handbook of Experimental Pharmacology edited by C. S. Cooper and P. L. Grover, Springer Verlag, New York, NY, 1989, pp. 63-102.

501. Hoffmann, D. and I. Hoffmann: On the reduction of nicotine in cigarette smoke; in: Nicotine, Smoking, and the Low-Tar Programme; edited by N. Wald and P. Froggatt, Oxford University Press, Oxford, UK, 1989, pp. 200-211.

502. LaVoie, E.J., P. Tucciarone, M. Kagan, J.D. Adams, and D. Hoffmann: Analysis of steam distillates and aqueous extracts of smokeless tobacco; J. Agric. Food Chem. 37 (1989) 154-157.

503. Melikian, A.A., K. Bagheri, B.F. Goldin, and D. Hoffmann: Catechol-induced alterations in metabolic activation and binding of enantiomeric and racemic 7,8-dihydroxy-7,8dihydrobenzo $(a)$ pyrene to DNA in mouse skin; Carcinogenesis 10 (1989) 1863-1870.

504. Melikian, A.A., K. Bagheri, S.S. Hecht, and D. Hoffmann: Metabolism of benzo[ $a]$ pyrene and $7-\beta, 8-\alpha$-dihydroxy-9$\alpha, 10$ - $\alpha$-epoxy-7,8,9,10-tetrahydrobenzo $[a]$ pyrene in lung and liver of newborn mice; Chem.-Biol. Interact. 69 (1989) 245-257.

505. Melikian, A.A., S.S. Hecht, and D. Hoffmann: [A Study of Tobacco Carcinogenesis. XL.] Mechanistic studies of tobacco carcinogenesis in mouse epidermis and lung tissues; in: Skin Carcinogenesis: Mechanisms and Human Relevance; edited by T.J. Slaga et al., A.R. Liss, Inc., New York, NY, 1989, pp. 331-345.

506. Melikian, A.A., K.G. Jordan, J. Braley, J. Rigotty, C.L. Meschter, S.S. Hecht, and D. Hoffmann: Effects of catechol on the induction of tumors in mouse skin by 7,8-dihydroxy7,8-dihydrobenzo[a]pyrenes; Carcinogenesis 10 (1989) 1897-1900.

507. Rivenson, A., M.V. Djordjevic, S. Amin, and D. Hoffmann: A Study of Tobacco Carcinogenesis. XLIV. Bioassay in A/J mice for some $N$-nitrosamines; Cancer Lett. 47 (1989) 111-114.

508. Brunnemann, K.D., J.E. Cox, M.R. Kagan, and D. Hoffmann: [Chemical Studies on Tobacco Smoke. XCIV.] Analysis of selected environmental tobacco smoke components in indoor air by thermal desorption-GC-MS; presented at the CORESTA Symposium, Kallithea, Greece, 1990, No. S10; in: Proc. CORESTA Symposium, Kallithea, Greece, 1990, pp. 100-107.

509. Brunnemann, K.D., J.E. Cox, M.R. Kagan, and D. Hoffmann: Application of thermal desorption for the analysis of environmental tobacco smoke (ETS); presented at the $44^{\text {th }}$ TCRC, Winston-Salem, NC, 1990, No. 27.

510. Brunnemann, K.D. and D. Hoffmann: Analytical studies on tobacco-specific $N$-nitrosamines in tobacco and tobacco smoke; J. Cancer Res. Clin. Oncol. 116 (Suppl. Pt. 2) (1990) 1087.

511. Brunnemann, K.D., M.R. Kagan, J.E. Cox, and D. Hoffmann: [Chemical Studies on Tobacco Smoke. LXXXVIII.] Analysis of 1,3-butadiene and other selected gas phase components in cigarette mainstream and sidestream smoke by gas chromatography-mass selective detection; Carcinogenesis 11 (1990) 1863-1868.

512. Djordjevic, M.V., D. Desai, C. Sigountos, K.D. Brunnemann, and D. Hoffmann: Mechanistic studies on the formation of 4-(methylnitrosamino)-4-(3-pyridyl)butyric acid and other tobacco-specific nitrosamines during tobacco processing; presented at the $44^{\text {th }}$ TCRC, Winston-Salem, NC, 1990 , No. 43.

513. Djordjevic, M.V., C.W. Sigountos, K.D. Brunnemann, and D. Hoffmann: [Chemical Studies on Tobacco Smoke. XCIII.] Tobacco-specific nitrosamine delivery in the mainstream smoke of high- and low-yield cigarettes smoked with varying puff volumes; presented at the CORESTA Symposium, Kallithea, Greece, 1990, No. S04; in: Proc. CORESTA Symp. Kallithea, Greece, 1990, pp. 54-62.

514. Haley, N.J., D.W. Sepkovic, K.D. Brunnemann, and D. Hoffmann: ETS uptake in nonsmokers after exposure to high-yield and low-yield cigarettes; in: Proceedings of the $5^{\text {th }}$ 
International Conf. on Indoor Air Quality and Climate, Toronto, Canada, Vol. 2, 1990, pp. 183-188.

515. Hoffmann, D., S. Amin, K.D. Brunnemann, B. Prokopczyk, A. Rivenson, and S.S. Hecht: Tobacco-specific $N$-nitrosamines: analysis, bioassays and biochemical studies; in: $N$ Nitroso Compounds: Biology and Chemistry; edited by S.V. Bhide and K.V.K. Rao, Omega Scientific Publishers, New Delhi, India, 1990, pp. 59-79.

516. Hoffmann, D., N.J. Haley, and E.L. Wynder: [A Study of Tobacco Carcinogenesis. XLV.] Laboratory studies on the association of cigarette smoking with cancer of the uterine cervix; J. Smoking Rel. Dis. 1 (1990) 15-23.

517. Melikian, A.A., K. Bagheri, and D. Hoffmann: Oxidation and DNA binding of (+)-7,8-dihydroxy-7,8-dihydrobenzo $[a]$ pyrene in mouse epidermis in vivo and effects of co-administration of catechol; Cancer Res. 50 (1990) 1795-1799.

518. Miyashita, M., J.C. Willey, K. Sasajima, J.F. Lechner, E.J. LaVoie, D. Hoffmann, M. Smith, B.F. Trump, and C.C. Harris: Differential effects of cigarette smoke condensate and its fractions on cultured normal and malignant human bronchial epithelial cells; Exp. Pathol. 38 (1990) 19-29.

519. Murphy, S.E., A. Palomino, S.S. Hecht, and D. Hoffmann: Dose response study of DNA and hemoglobin adduct formation by 4-(methylnitrosamino)-1-(3-pyridyl)-1 butanone in F344 rats; Cancer Res. 50 (1990) 5446-5452.

520. Prokopczyk, B., A. Sharma, J.E. Cox, K.D. Brunnemann, and D. Hoffmann: Application of supercritical fluid extraction for the analysis of selected components in chewing tobaccos; presented at the $44^{\text {th }}$ TCRC, Winston-Salem, NC, 1990, No. 69.

521. Anderson, L.M., S.S. Hecht, R.M. Kovatch, S. Amin, D. Hoffmann, and J.M. Rice: Tumorigenicity of the tobaccospecific carcinogen 4-(methylnitrosamino)-1-(3-pyridyl)-1butanone in infant mice; Cancer Lett. 58 (1991) 177-181.

522. Brunnemann, K.D., M.V. Djordjevic, R. Feng, and D. Hoffmann: Analysis and pyrolysis of some $N$-nitrosamino acids in tobacco and tobacco smoke; in: Relevance to Human Cancer of $N$-Nitroso Compounds, Tobacco Smoke and Mycotoxins, IARC Sci. Publ. 105 (1991) 477-481.

523. Brunnemann, K.D. and D. Hoffmann: [Chemical Studies on Tobacco Smoke. XCIII.] Analytical studies on tobaccospecific $N$-nitrosamines in tobacco and tobacco smoke; Crit. Rev. Toxicol. 21 (1991) 235-240.

524. Brunnemann, K.D. and D. Hoffmann: [Chemical Studies on Tobacco Smoke. XCVII.] Analytical studies on $N$-nitrosamines in tobacco and tobacco smoke; presented at the $45^{\text {th }}$ TCRC, Asheville, NC, 1991, No. 3; in: Rec. Adv. Tobacco Sci. 17 (1991) 71-112.

525. Brunnemann, K.D. and D. Hoffmann: Methods of analysis for tobacco-specific $N$-nitrosamines in indoor air; presented at the $45^{\text {th }}$ TCRC, Asheville, NC, 1991, No. 50.

526. Brunnemann, K.D. and D. Hoffmann: [Chemical Studies on Tobacco Smoke. XC.] Decreased concentrations of $\mathrm{N}$ nitrosodiethanolamine and $N$-nitrosomorpholine in commercial tobacco products; J. Agric. Food Chem. 39 (1991) 207-208.

527. Djordjevic, M.V., J. Krzeminski, K.D. Brunnemann, and D. Hoffmann: Identification and quantitative analysis of new $N$ nitrosamino acids in snuff tobacco; presented at the $45^{\text {th }}$ TCRC, Asheville, NC, 1991, No. 16.

528. Djordjevic, M.V., C.M. Sigountos, K.D. Brunnemann, and D. Hoffmann: [Chemical Studies on Tobacco Smoke. LXXXIX.] Formation of 4-(methylnitrosamino)-4-(3pyridyl)butyric acid in vitro and in mainstream cigarette smoke; J. Agric. Food Chem. 39 (1991) 209-213.

529. Djordjevic, M.V., C.W. Sigountos, D. Hoffmann, K.D. Brunnemann, M.R. Kagan, L.P. Bush, R.D. Safaev, G.A. Belitsky, and D. Zaridze: Chemical Studies on Tobacco
Smoke. XCI. Assessment of major carcinogens and alkaloids in the tobacco and mainstream smoke of USSR cigarettes; Int. J. Cancer 47 (1991) 348-351.

530. Hecht, S.S., N.J. Haley, and D. Hoffmann: Monitoring exposure to tobacco products by measurement of nicotine metabolites and derived carcinogens; in: Molecular Dosimetry and Human Cancer: Analytical, Epidemiological, and Ethical Considerations; edited by J.D. Groopman and P.L. Skipper, CRC Press, Boca Raton, FL, 1991, pp. 325-361.

531. Hecht, S.S. and D. Hoffmann: 4-(Methylnitrosamino)-1-(3pyridyl)-1-butanone (NNK), a nicotine-derived tobaccospecific nitrosamine, and cancer of the lung and pancreas in humans; in: Origin of Human Cancer: A Comprehensive Review, Cold Spring Harbor Laboratory Press, Cold Spring Harbor, NY, 1991, pp. 745-755.

532. Hecht, S.S. and D. Hoffmann: $N$-Nitroso compounds and tobacco-induced cancer in man; in: Relevance to Human Cancer of $N$-Nitroso Compounds, Tobacco Smoke and Mycotoxins, IARC Sci. Publ. 105 (1991) 54-61.

533. Hoffmann, D., M.V. Djordjevic, and K.D. Brunnemann: [Chemical Studies on Tobacco Smoke. XCII.] New brands of oral snuff. (Brief Communication); Food Chem. Toxicol. 29 (1991) 65-68.

534. Hoffmann, D., M.V. Djordjevic, and K.D. Brunnemann: On the control of toxic substances in smokeless tobacco; J. Smoking Related Dis. 3 (1991) 165-172.

535. Hoffmann, D., N.J. Haley, M. Djordjevic, K.D. Brunnemann, and S.S., Hecht: Biomarkers of exposure to tobacco products; in: Human Carcinogen Exposure: Biomonitoring and Risk Assessment; edited by R.C. Garner et al., IRL Press, Oxford, UK, 1991, pp. 275-283.

536. Hoffmann, D., I. Hoffmann, and E.L. Wynder: Lung cancer and the changing cigarette; in: Relevance to Human Cancer of $N$-Nitroso Compounds, Tobacco Smoke and Mycotoxins; IARC Sci. Publ. 105 (1991) 449-459.

537. Hoffmann, D., A.A. Melikian, and K.D. Brunnemann: Studies in tobacco carcinogenesis; in: Relevance to Human Cancer of $\mathrm{N}$-Nitroso Compounds, Tobacco Smoke and Mycotoxins; IARC Sci. Publ. 105 (1991) 482-484.

538. Hoffmann, D., A. Rivenson, F.-L. Chung, and S.S. Hecht: Relevance of Nicotine-derived $\mathrm{N}$-Nitrosamines in Tobacco Carcinogenesis; in: Effects of nicotine on biological systems; edited by F. Adlkofer and K. Thurau, Birkhäuser Publ., Boston, MA, 1991, pp. 89-101.

539. Hoffmann, D., A. Rivenson, F.-L. Chung, and S.S. Hecht: Nicotine-derived $N$-nitrosamines (TSNA) and their relevance in tobacco carcinogenesis; Crit. Rev. Toxicol. 21 (1991) 305-311.

540. Matsukura, N., J. Willey, M. Miyashita, B. Taffe, D. Hoffmann, C. Waldren, T.T. Puck, and C.C. Harris: Detection of direct mutagenicity of cigarette smoke condensate in mammalian cells; Carcinogenesis 12 (1991) 685-689.

541. Melikian, A.A., K. Bagheri, S.S. Hecht, and D. Hoffmann: Comparative metabolism and disposition of benzo $[a]$ pyrene and 7- $\beta, 8$ - $\alpha$-dihydroxy- 9 - $\alpha, 10$ - $\alpha$-epoxy-7,8,9,10-tetrahydrobenzo $[a]$ pyrene in mouse epidermis and in the lungs of newborn mice in vivo; in: Polynuclear Aromatic Hydrocarbons: Measurements, Means, and Metabolism; edited by M. Cooke et al., Battelle Press, Columbus, OH, 1991, pp. 571-581.

542. Mitacek, E.J., K.D. Brunnemann, A.P. Polednak, D. Hoffmann, and M. Suttajit: [Chemical Studies on Tobacco Smoke. XCV.] Composition of popular tobacco products in Thailand, and its relevance to disease prevention; Prev. Med. 20 (1991) 764-773.

543. Prokopczyk, B., D. Hoffmann, J.E. Cox, M.V. Djordjevic, and K.D. Brunnemann: Application of supercritical fluid extraction for the analysis of tobacco-specific $\mathrm{N}$-nitrosamines in tobacco; presented at the $45^{\text {th }}$ TCRC, Asheville, 
NC, 1991, No. 15.

544. Prokopczyk, B., A. Rivenson, and D. Hoffmann: A Study of Betel Quid Carcinogenesis IX. Comparative carcinogenicity of 3-(methylnitrosamino)propionitrile and 4-(methylnitrosamino)-1-(3-pyridyl)-1-butanone upon local application to mouse skin and rat oral mucosa; Cancer Lett. 60 (1991) 153-157.

545. Rivenson, A., S.S. Hecht, and D. Hoffmann: Carcinogenicity of tobacco-specific $N$-nitrosamines (TSNA): the role of the vascular network in the selection of target organs; Crit. Rev. Toxicol. 21 (1991) 255-264.

546. Rivenson, A. and D. Hoffmann: Extensive spontaneous occlusive arteriosclerosis of the lingual arteries in Fischer rats, a model for the study of human occlusive arteriosclerosis of medium- and small-sized arteries; Artery 18 (1991) 150-162.

547. Sharma, A.K., B. Prokopczyk, and D. Hoffmann: [Chemical Studies on Tobacco Smoke. XCII.] Supercritical fluid extraction of moist snuff; J. Agric. Food Chem. 39 (1991) 508-510.

548. Zaridze, D.G., R.D. Safaev, G.A. Belitsky, K.D. Brunnemann, and D. Hoffmann: Carcinogenic substances in Soviet tobacco products; in: Relevance to Human Cancer of $\mathrm{N}$ Nitroso Compounds, Tobacco Smoke and Mycotoxins, IARC Sci. Publ. 105 (1991) 485-488.

549. Brunneman, K.D., J.E. Cox, and D. Hoffmann: [Chemical Studies on Tobacco Smoke. XCVIII.] Analysis of tobaccospecific $N$-nitrosamines in indoor air; Carcinogenesis 13 (1992) 2415-2418.

550. Brunneman, K.D., J.E. Cox, Y. Liu, and D. Hoffmann: Analysis of volatile and tobacco-specific $N$-nitrosamines in tobacco smoke by conventional method and by supercritical fluid extraction; presented at the $46^{\text {th }}$ TCRC, Montreal, Canada, 1992, No. 22.

551. Brunnemann, K.D. and D. Hoffmann: Chemical composition of smokeless tobacco products; in: Smokeless tobacco or health: An international perspective; edited by D.R. Shopland et al., Smoking and Tobacco Control Monogr. 2, NCI, Bethesda, MD, 1992, pp. 96-108.

552. Brunnemann K.D. and D. Hoffmann: Analysis of tobaccospecific $N$-nitrosamines in tobacco and tobacco smoke; presented at the $204^{\text {th }}$ Natl. Meeting Am. Chem. Soc., Washington, DC, 1992, No. 161.

553. Brunnemann, K.D., B. Prokopczyk, M.V. Djordjevic, J.E. Cox, and D. Hoffmann: The use of supercritical fluid extraction for the analysis of tobacco-specific $\mathrm{N}$-nitrosamines in tobacco and in tobacco smoke; presented at the CORESTA Congress, Jerez de la Frontera, 1992, No. ST10

554. Brunnemann, K.D., A. Rivenson, S.C. Cheng, V. Saa, and D. Hoffmann: A Study of Tobacco Carcinogenesis. XLVII. Bioassays of vinylpyridines for genotoxicity and for tumorigenicity in A/J mice; Cancer Lett. 65 (1992) 107-113.

555. Djordjevic, M.V., K.D. Brunnemann, and D. Hoffmann: The occurence of $\mathrm{N}$-nitrosamino acids in commercial tobacco products and effect of storage conditions on their levels; presented at the $46^{\text {th }}$ TCRC, Montreal, Canada, 1992, No. 23.

556. Djordjevic, M.V., D. Hoffmann, K.D. Brunnemann, L.P. Bush: Effect of storage conditions on the levels of tobaccospecific nitrosamines, alkaloids and nitrite in US commercial moist snuff; presented at the CORESTA Congress, Jerez de la Frontera, 1992, No. ST17.

557. Djordjevic, M.V., J. Krzeminski, K.D. Brunnemann, and D. Hoffmann: Characterization of $N$-nitrosamino acids in tobacco products and assessment of their carcinogenic potential; presented at the $204^{\text {th }}$ Natl. Meeting, Am. Chem. Soc., Washington, DC, 1992, No. 160.

558. Hoffmann, D., K.D. Brunnemann, I. Hoffmann, A. Rivenson, and S.S. Hecht: Advances in Tobacco Carcinogenesis.
II. Cigarette smoke; in: Control of Tobacco-related Cancers and Other Diseases; edited by P.C. Gupta et al., Oxford University Press, Bombay, India, 1992, pp. 205-216.

559. Hoffmann, D., S.S. Hecht, and E.L. Wynder: Cancer of the upper aerodigestive tract: environmental factors and prevention; J. Tobacco Rel. Dis. 3 (1992) 109-129.

560. Hoffmann, D., A. Rivenson, and S.S. Hecht: Carcinogenesis of Smokeless Tobacco; in: Smokeless tobacco or health: An international perspective; edited by D.R. Shopland et al., Smoking and Tobacco Control Monogr. 2, NCI, Bethesda, MD, 1992, pp. 109-118.

561. Hoffmann, D., A. Rivenson, B. Prokopczyk, K.D. Brunnemann, S.G. Carmella, and I. Hoffmann: Advances in Tobacco Carcinogenesis I. Smokeless tobacco and betel quid; in: Control of Tobacco-Related Cancers and Other Diseases; edited by P.C. Gupta et al., Oxford University Press, Bombay, India, 1992, pp. 193-204.

562. Hoffmann, D., A. Rivenson, E.L. Wynder, and S.S. Hecht: Formation of tobacco-specific $N$-nitrosamines, their carcinogenicity, and the role of dietary fat in their carcinogenicity; presented at the $204^{\text {th }}$ Natl. Meeting, Am. Chem. Soc., Washington, DC, 1992, No. 119.

563. Koppang, N., A. Rivenson, A. Reith, H.K. Dahle, Ö. Eversen, and D. Hoffmann: A Study of Tobacco Carcinogenesis. XLVIII. Carcinogenicity of $N$ '-nitrosonornicotine in mink (Mustela vison); Carcinogenesis 13 (1992) 1957-1960.

564. Murphy, S.E., S. Amin, K. Coletta, and D. Hoffmann: Rat liver metabolism of benzo[b]naphtho[2,1-d]thiophene; Chem. Res. Toxicol. 5 (1992) 491-495.

565. Nishikawa, A., B. Prokopczyk, A. Rivenson, E. Zang, and D. Hoffmann: A Study of Betel Quid Carcinogenesis VIII. Carcinogenicity of 3-(methylnitrosamino)propionaldehyde in F344 rats; Carcinogenesis 13 (1992) 369-372.

566. Prokopczyk, B., D. Hoffmann, J.E. Cox, M.V. Djordjevic, and K.D. Brunnemann: [Chemical Studies on Tobacco Smoke. XCVI.] Supercritical fluid extraction in the determination of tobacco-specific $N$-nitrosamines in smokeless tobacco; Chem. Res. Toxicol. 5 (1992) 336-340.

567. Prokopczyk, B., M. Wu, J.E. Cox, and D. Hoffmann: [A Study of Tobacco Carcinogenesis. XLVI.] Bioavailability of tobacco-specific $N$-nitrosamines to the snuff dipper; Carcinogenesis 13 (1992) 863-866.

568. Safaev, R., G.A. Belitskii, T.A. Licheva, I.A. Khitrovo, S.Y. Fukhs, L.V. Krivosheyeva, D. Hoffmann, K.D. Brunnemann, and M.V. Djordjevic: The effect of cigarette filter modification on the content of chemical carcinogens in cigarette smoke and genotoxicity of condensate; Eksp. Onkol. 14 (1992) 24-27.

569. Safaev, R., D.G. Zaridze, G.A. Belitskii, M.V. Djordjevic, D. Hoffmann, K.D. Brunnemann, Y.A. Perezhogina, N.N. Sokolskaya, A. Goginasvili, and Y. Khesina: Carcinogenic substances in the tobacco and smoke of cigarettes: Polynuclear aromatic hydrocarbons, metals, pesticides; Eksp. Onkol. 14 (1992) 25-29.

570. Brunnemann, K.D., J.E. Cox, and D. Hoffmann: Determination of cadmium in cigarette smoke and its possible role as biomarker; presented at the $47^{\text {th }}$ TCRC, Gatlinburg, TN, 1993, No. 20

571. Djordjevic, M.V., K.D. Brunnemann, and D. Hoffmann: The need for regulation of carcinogenic $N$-nitrosamines in oral snuff; Food Chem. Toxicol. 31 (1993) 497-501.

572. Djordjevic, M.V., J. Fan, K.D. Brunnemann, and D. Hoffmann: In vitro nitrosation of nicotine and some of its metabolites under physiological conditions; presented at the $47^{\text {th }}$ TCRC, Gatlinburg, TN, 1993, No. 12.

573. Djordjevic, M.V., J. Fan, L.P. Bush, K.D. Brunnemann, and D. Hoffmann: Effects of storage conditions on levels of tobacco-specific $N$-nitrosamines and $N$-nitrosamino acids in 
US moist snuff; J. Agric. Food, Chem. 41(1993) 1790-1794.

574. Hecht, S.S., S.G. Carmella, S.E. Murphy, S. Akerkar, K.D. Brunnemann, and D. Hoffmann: A Tobacco-specific Lung Carcinogen in the Urine of Men Exposed to Cigarette Smoke; New Engl. J. Med. 329 (1993) 1543-1546.

575. Hoffmann, D.: Analysis of toxic smoke constituents; in: U.S. Consumer Product Safety Commission. Fire Safe Cigarette Act of 1990. Toxicity Testing. Vol. 5; edited by B.C. Lee, Washington, DC, 1993, pp. D1-D38.

576. Hoffmann, D: In vivo bioassays for carcinogenicity. U.S. Consumer Product Safety Commission. Fire Safe Cigarette Act of 1990. Toxicity Testing. Vol. 5; edited by B.C. Lee, Washington, DC, 1993, pp. F1-F17.

577. Hoffmann, D., M.V. Djordjevic, A. Rivenson, E. Zang, D. Desai, and S. Amin: A Study of Tobacco Carcinogenesis. LI. Relative potencies of tobacco-specific $N$-nitrosamines as inducers of lung tumors in A/J mice; Cancer Lett.71 (1993) $25-30$.

578. Hoffmann, D. and I. Hoffmann: Tobacco smoke as a respiratory carcinogen; in: Prevention of Respiratory Disease; edited by A. Hirsch et al., Marcel Dekker Inc., New York, NY, Vol. 68, 1993, pp. 497-532.

579. Hoffmann, D., A. Rivenson, R. Abbi, and E.L. Wynder: A Study of Tobacco Carcinogenesis [L.]: Effect of the fat content of the diet on the carcinogenic activity of 4(methylnitrosamino)-1-(3-pyridyl)-1-butanone in F344 rats; Cancer Res. 53 (1993) 2758-2761.

580. Hoffmann, D., A. Rivenson, F.-L. Chung, and E.L. Wynder: Potential inhibitors of tobacco carcinogenesis; Ann. NY Acad. Sci. 686 (1993) 140-160.

581. Hoffmann, D., A. Rivenson, S.E. Murphy, F.-L. Chung, S. Amin, and S.S.Hecht: Cigarette smoking and adenocarcinoma of the lung: the relevance of nicotine-derived $\mathrm{N}$ nitrosamines; J. Smoking Related Dis. 4 (1993) 165-189.

582. Melikian, A.A., A.K. Prahalad, and D. Hoffmann: [A Study of Tobacco Carcinogenesis. XLIX.] Urinary trans, transmuconic acid as an indicator of exposure to benzene in cigarette smokers; Cancer Epidemiol. Biomarkers Prev. 2 (1993) 47-51.

583. Brunnemann, K.D. and D. Hoffmann: Analysis of tobaccospecific nitrosamines in tobacco and tobacco smoke; in: Nitrosamines and Related $N$-Nitroso Compounds. Chemistry and Biochemistry; edited by R.N. Loeppky and C.J. Michejda, Am. Chem. Soc. Monogr. 553 (1994) 369-371.

584. Brunnemann, K.D. and D. Hoffmann: Analysis of selected mainstream smoke components of low ignition propensity cigarettes; presented at the $48^{\text {th }}$ TCRC, Greenboro, NC, 1994, No. 54.

585. Brunnemann, K.D., D. Hoffmann, C.G. Gairola, and B.C. Lee: [Chemical Studies on Tobacco Smoke. XCIX.] Low ignition propensity cigarettes: smoke analysis for carcinogens and testing for mutagenic activity of the smoke particulate matter; Food Chem. Toxicol. 32 (1994) 917-922.

586. Djordjevic, M.V., J. Fan, and D. Hoffmann: Chlorinated pesticide residues in tobacco products: analysis based on supercritical fluid extraction; presented at the $48^{\text {th }}$ TCRC, Greenboro, NC, 1994, No. 49.

587. Djordjevic, M.V., J. Fan, J. Krzeminski, K.D. Brunnemann, and D. Hoffmann: Characterization of $N$-nitrosamino acids in tobacco products and assessment of their carcinogenic potential; in: Nitrosamines and Related $\mathrm{N}$-Nitroso Compounds. Chemistry and Biochemistry; edited by R.N. Loeppky and C.J. Michejda, Am. Chem. Soc. Monogr. 553 (1994) 367-368.

588. Djordjevic, M.V., D. Hoffmann, J. Fan, B. Prokopczyk, M.L. Citron, and S.D. Stellman: Assessment of chlorinated pesticide and polychlorinated biphenols in adipose breast tissue using a supercritical fluid extraction method; Carcinogenesis 15 (1994) 2581-2585.
589. Hecht, S.S., S.E. Murphy, and D. Hoffmann: Tobaccospecific lung carcinogen and exposure to passive smoking; New Eng. J. Med. 330 (1994) 1016-1017.

590. Hoffmann, D., K.D. Brunnemann, B. Prokopczyk, and M.V. Djordjevic: Tobacco-specific $N$-nitrosamines and arecaderived $N$-nitrosamines: chemistry, biochemistry, carcinogenicity and relevance to humans; J. Toxicol. Environ. Health 41 (1994) 1-52.

591. Hoffmann, D. and I. Hoffmann: Recent developments in smoking related cancer research; J. Smoking Rel. Disord. 5 (1994) 77-93.

592. Hoffmann, D. and I. Hoffmann: Tobacco Consumption and Lung Cancer; in: Lung Cancer. V. Advances in Basic and Clinical Research; edited by H.H. Hansen, Kluwer Academic Publ., Boston, MA, 1994, pp. 1-42.

593. Hoffmann, D., A. Rivenson, E.L. Wynder, and S.S. Hecht: Formation of tobacco-specific nitrosamines: Carcinogenicity, and the role of dietary fat in their carcinogenicity; in: Nitrosamines and Related $N$-Nitroso Compounds. Chemistry and Biochemistry; edited by R.N. Loeppky and C.J. Michejda, Am. Chem. Soc. Monogr. 553 (1994) 267-278.

594. Hoffmann, D. and E.L. Wynder: Aktives und Passives Rauchen [Active and passive smoking]; in: Lehrbuch der Toxikologie; edited by H. Marquardt and S.G. Schaefer, B.I. Wissenschaftsverlag, Mannheim, Germany, 1994, pp. 589-605.

595. Idris, A.M., B. Prokopczyk, and D. Hoffmann: Toombak: a major risk factor for cancer of the oral cavity in Sudan; Prev. Med. 23 (1994) 832-839.

596. Murphy, S.E., S.G. Carmella, A.M. Idris, and D. Hoffmann: Uptake and metabolism of carcinogenic levels of tobaccospecific nitrosamines by Sudanese snuff dippers; Cancer Epidemiol. Biomarkers Prev. 3 (1994) 423-428.

597. Prokopczyk, B., J. Krzeminski, and D. Hoffmann: Significance of nitrosamines in betel quid carcinogenesis; in: Nitrosamines and Related $N$-Nitroso Compounds. Chemistry and Biochemistry; edited by R.N. Loeppky and C.J. Michejda, Am. Chem. Soc. Monogr. 553 (1994) 365-366.

598. Prokopczyk, B., M. Wu, J.E. Cox, S. Amin, D. Desai, and D. Hoffmann: The application of supercritical fluid extraction (SFE) for the determination of tobacco-specific nitrosamines in various tobacco samples. II. Optimization of the methodology; presented at the $48^{\text {th }}$ TCRC, Greensboro, NC, 1994, No. 45 .

599. Wynder, E.L. and D. Hoffmann: Smoking and lung cancer: Scientific challenges and opportunities; Cancer Res. 54 (1994) 5284-5295

600. Djordjevic, M.V., J. Fan, S. Ferguson, and D. Hoffmann: Self-regulation of smoking intensity. Smoke yields of the low-nicotine, low-"tar" cigarettes; Carcinogenesis 16(1995) 2015-2021.

601. Djordjevic, M.V., J. Fan, S. Ferguson, and D. Hoffmann: The chemical composition of mainstream cigarette smoke generated under FTC/CORESTA and actual human smoking (AHS) conditions; presented at the CORESTA Meet. Smoke-Techno Groups, Vienna, Austria, 1995, No. ST22.

602. Djordjevic, M.V., J. Fan, and D. Hoffmann: Assessment of chlorinated pesticide residues in cigarette tobacco based on supercritical fluid extraction and GC-ECD; Carcinogenesis 16 (1995) 2627-2632.

603. Djordjevic, M.V. and D. Hoffmann: Nicotine, $\mathrm{pH}$, and $\mathrm{N}$ nitrosamines in US commercial moist snuff brands; presented at the $49^{\text {th }}$ TCRC, Lexington, KY, 1995, No. 35.

604. Djordjevic, M.V., D. Hoffmann, T. Glynn, and G.N. Connolly: US commercial brands of moist snuff, 1994. I. Assessment of nicotine, moisture, and $\mathrm{pH}$; Tob. Control 4 (1995) 62-66.

605. Hoffmann, D., M.V. Djordjevic, and K.D. Brunnemann: Changes in cigarette design and composition over time and 
how they influence the yields of smoke constituents; J. Smoking Rel. Disord. 6 (1995) 9-23.

606. Hoffmann, D., M.V. Djordjevic, J. Fang, E. Zang, T. Glynn, and G.C. Connolly: Five leading US commercial brands of moist snuff in 1994: assessment of carcinogenic $N$-nitrosamines; J. Natl. Cancer Inst. 87 (1995) 1862-1869.

607. Hoffmann, D. and I. Hoffmann: Tobacco consumption and lung cancer; Cancer Treat Res. 72 (1995) 1-42.

608. Muscat, J.E., D. Hoffmann, and E.L. Wynder: The epidemiology of renal cell carcinoma: a second look; Cancer 75 (1995) 2552-2557.

609. Prokopczyk, B, J.E. Cox, D. Pullo, and D. Hoffmann: GCSRM-MS/MS for the analysis of TSNA in biological samples; presented at the $49^{\text {th }}$ TCRC, Lexington, KY, 1995 , No. 36.

610. Prokopczyk, B., M. Wu, S. Amin, D. Desai, A.M. Idris, and D. Hoffmann: Improved methodology for the quantitative assessment of tobacco-specific $N$-nitrosamines in tobacco by supercritical fluid extraction; J. Agric. Food Chem. 43 (1995) 916-922.

611. Safaev, R.D., D.G. Zaridze, D. Hoffmann, K.D. Brunnemann, and Y. Liu: Efficiency and assessment of new cigarette filters. Chemical analysis of some of the toxic and carcinogenic agents in the mainstream smoke; Exper. Oncol. 17 (1995) 71-76.

612. Amin, S., D. Desai, S.S. Hecht, and D. Hoffmann: Synthesis of tobacco-specific $N$-nitrosamines and their metabolites and results of related bioassays; Crit. Rev. Toxicol. 26 (1996) 139-147.

613. Brunnemann, K.D., B. Prokopczyk, M.V. Djordjevic, and D. Hoffmann: Formation and analysis of tobacco-specific $N$ nitrosamines; Crit. Rev. Toxicol. 26 (1996) 121-137.

614. Djordjevic, M.V., L. Eixarch, L.P. Bush, and D. Hoffmann: A comparison of the yields of selected components in the mainstream smoke of the leading US and Japanese cigarettes; presented at the CORESTA Congress Yokohama, Japan, 1996, No. S10; in: CORESTA Proc. Joint SmokeTechnology Groups, Yokohama, Japan, 1996, pp. 200-217.

615. Djordjevic, M.V., J. Fan, S. Akerkar, J. Heidbrink, J.P. Richie Jr, and D. Hoffmann: Effects of smokers' compensation for nicotine on mainstream smoke chemistry and urinary biomarkers of exposure; presented at the $50^{\text {th }} \mathrm{TCRC}$, Richmond, VA, 1996, No. 64.

616. El-Bayoumy, K., B. Prokopczyk, L.A. Peterson, D. Desai, S. Amin, B.S. Reddy, D. Hoffmann, and E.L. Wynder: Effects of dietary fat content on the metabolism of NNK and on DNA methylation induced by NNK; Nutr. Cancer, 26 (1996) 1-10.

617. El-Bayoumy, K., P. Upadhyaya, D.H. Desai, S. Amin, D. Hoffmann, and E.L. Wynder: Effects of 1,4-phenylenebis(methylene)selenocyanate, phenylethyl isothiocyanate, indole-3-carbinol, and $d$-limonene individually and in combination on the tumorigenicity of the tobacco-specific nitrosamine 4-(methylnitrosamino)-1-(3-pyridyl)-1-butanone in A/J mouse lung; Anticancer Res. 16 (1996) 2709-2712.

618. Hoffmann, D., M.V. Djordjevic, and K.D. Brunnemann: Changes in cigarette design and composition over time and how they influence the yields of smoke constituents; in: The FTC cigarette test method for determining tar, nicotine, and carbon monoxide yields of US cigarettes; NIH/NCI. Smoking and Tobacco Control Monogr. 7, NCI, Bethesda, MD, 1996, pp. 15-37.

619. Hoffmann, D., A.A. Melikian, and E.L. Wynder: Scientific challenges in environmental carcinogenesis; Prev. Med. 25 (1996) 14-22.

620. Hoffmann, D., A. Rivenson, and S.S. Hecht: The biological significance of tobacco-specific $N$-nitrosamines: smoking and adenocarcinoma of the lung; Crit. Rev. Toxicol. 26 (1996) 199-211.
621. Lazarus, P., A.M. Idris, J. Kim, A. Calcagnotto, and D. Hoffmann: p53 mutations in head and neck squamous carcinomas from Sudanese snuff (Toombak) users; Cancer Detect. Prev. 20 (1996) 270-278.

622. Prokopczyk, B., J.E. Cox, P. Upadhyaya, S. Amin, D. Desai, D. Hoffmann, and K. El-Bayoumy: Effects of dietary 1,4phenylenebis(methylene)selenocyanate on 4-(methylnitrosamino)-1-(3-pyridyl)-1-butanone-induced DNA adduct formation in lung and liver of A/J mice and F-344 rats; Carcinogenesis 17 (1996) 749-753.

623. Djordjevic, M.V., L. Eixarch, and D. Hoffmann: Selfadministered and effective dose of cigar smoke constituents; pres. at the $51^{\text {st }}$ TCRC, Winston-Salem, NC, 1997, No. 9.

624. Djordjevic, M.V., D. Hoffmann, S. Thompson, and S.D. Stellman: Distribution of smoking parameters and selfadministered doses of select smoke components among different population groups; presented at the CORESTA Meet. Smoke-Techno Groups, Hamburg, 1997, No. ST7; in: CORESTA Proc. Smoke-Techno Groups, Hamburg, Germany, 1997, pp. 44-61.

625. Djordjevic, M.V., D. Hoffmann, and I. Hoffmann: Nicotine regulates smoking patterns; Prev. Med. 26 (1997) 435-440.

626. Hoffmann, D. and M.V. Djordjevic: Chemical composition and carcinogenicity of smokeless tobacco; Adv. Dental Res. 11 (1997) 322-329.

627. Hoffmann, D., M.V. Djordjevic, and I. Hoffmann: The changing cigarette; Prev. Med. 26 (1997) 427-434.

628. Hoffmann, D. and I. Hoffmann: [Chemical Studies on Tobacco Smoke. C.] The changing cigarette, 1950-1995. J. Toxicol Environ. Health 50 (1997) 307-364.

629. Hoffmann, D. and E.L. Wynder: Tobacco smoke; in: Encyclopaedia of Occupational Health and Safety; edited by J. Majer Stellman, ICLO Publications, Geneva, Switzerland. Vol. 2, 1997, pp. 44.11-44.14.

630. Koppang, N., A. Rivenson, H.K. Dahle, and D. Hoffmann: A Study of Tobacco Carcinogenesis. LIII. Carcinogenicity of $N^{\prime}$-nitrosonornicotine (NNN) and 4-(methylnitrosamino)1-(3-pyridyl)-1-butanone (NNK) in mink (Mustala vison); Cancer Lett. 111 (1997) 167-171.

631. Muscat, J.E., S.D. Stellman, D. Hoffmann, and E.L. Wynder: Smoking and pancreatic cancer in men and women; Cancer Epidemiol. Biomarkers Prev. 6 (1997) 15-19.

632. Prokopczyk, B., J.E. Cox, D. Hoffmann, and S.E.Waggoner: Identification of tobacco-specific carcinogen in the cervical mucus of smokers and nonsmokers; J. Natl. Cancer Inst. 89 (1997) 868-873.

633. Stellman, S.D., J.E. Muscat, D. Hoffmann, and E.L. Wynder: Impact of filter cigarette smoking on lung cancer histology; Prev. Med. 26 (1997) 451-456.

634. Stellman, S.D., J.E. Muscat, S. Thompson, D. Hoffmann, and E.L. Wynder: Risk of squamous cell carcinoma and adenocarcinoma of the lung in relation to lifetime filter cigarette smoking; Cancer 80 (1997) 382-388.

635. Burnes, D.M., D. Hoffmann, and K. M. Cummings (Editors): Cigar Smoking in the United States; NIH/NCI Smoking and Tobacco Control Monogr. 9, NCI, Bethesda, MD, 1998.

636. Djordjevic, M.V., D. Hoffmann, S. Thompson, and S.D. Stellman:. Tobacco and mainstream smoke chemistry of the leading U.S. and Japanese cigarettes; presented at the $52^{\text {nd }}$ Tobacco Science Research Conference (TSRC), Atlanta, GA, 1998, No. 59.

637. Djordjevic, M.V., D. Hoffmann, S. Thompson, and S.D. Stellman: Smoking behavior and exposure to selected toxic agents among smokers of low- and medium-yield cigarettes; presented at the CORESTA Congress Brighton, UK, 1998, No. ST16.

638. Hecht, S.S. and D. Hoffmann: $N$-Nitroso compounds and man: sources of exposure, endogenous formation, and 
occurrence in body fluids; [Correspondence] Europ. J. Cancer Prev. 7 (1998) 165-166.

639. Hoffmann, D. and I. Hoffmann: Letter to the Editor: Tobacco Smoke Components; Beitr. Tabakforsch. Int. 18 (1998) 49-52.

640. Hoffmann, D. and I. Hoffmann: Chemistry and Toxicology; in: Cigar Smoking in the United States; edited by D.M. Burnes et al., Smoking and Tobacco Control Monograph 9, NCI, Bethesda, MD, 1998, pp. 55-104.

641. Hoffmann, D., I. Hoffmann, and E.L. Wynder: The changing cigarette, 1950-1997: facts and expectations; in: Proc. Canadian Conf. of Cigarette Toxicity Reduction; edited by W.S. Rickert, Toronto, Canada, 1998, 94 p.

642. Prokopczyk, B., D. Hoffmann, N. Trushin, J.E. Cox, K. ElBayoumi, and S. Waggoner: In vitro studies on the metabolism of NNK in cervical tissue; presented at the $52^{\text {nd }}$ TSRC, Atlanta, GA, 1998, No. 63.

643. Wynder, E.L. and D. Hoffmann: Re: Cigarette Smoking and the Histopathology of Lung Cancer J. Natl. Cancer Inst. 90 (1998) 1486-1487.

644. El-Bayoumy, K. and D. Hoffmann: Nutrition and tobaccorelated cancer; in: Nutritional Oncology; edited by D. Heber et al., Academic Press, San Diego, CA, 1999, pp. 299-324.

645. El-Bayoumy, K., M. Iatropoulos, S. Amin, D. Hoffmann, and E.L.Wynder: Increased expression of cyclooxygenase-2 in rat lung tumors induced by the tobacco-specific nitrosamine 4-(methylnitrosamino)-1-(3-pyridyl)-1-butanone: the impact of a high-fat diet; Cancer Res. 59 (1999) 1400-1403.

646. Hoffmann, D., S. Amin, K.D. Brunnemann, D. Desai, and A.C. Collins: On the modulation of nicotine: Studies on 2methylnicotine; presented at the $53^{\text {rd }}$ TSRC, Montreal, Canada, 1999, No. 29.

647. Hoffmann, D. and I. Hoffmann: (Obituary) Ernst L. Wynder, MD, Dr Sc hc (mult) Dr med hc, 1922-1999; Tobacco Control 8 (1999) 444-445.

648. Hoffmann, D. and E.L. Wynder: Active and Passive Smoking; in: Toxicology; edited by H. Marquardt et al., Academic Press, San Diego, CA, 1999, pp. 879-898.

649. Kagan, M.R., J.A. Cunningham, and D. Hoffmann: Propylene glycol: a precursor of propylene oxide in cigarette smoke; presented at the $53^{\text {rd }}$ TSRC, Montreal, Canada, 1999, No. 41.

650. Melikian, A.A., P. Sun, B. Prokopczyk, K. El-Bayoumy, D. Hoffmann, X. Wang, and S. Waggoner: Identification of benzo $[a]$ pyrene metabolites in cervical mucus and DNA adducts in cervical tissues in humans by gas chromatography-mass spectrometry; Cancer Lett. 146 (1999) 127-134.

651. Melikian, A.A., X. Wang, S. Waggoner, D. Hoffmann, and K. El-Bayoumy: Comparative response of normal and of human papillomavirus-16 immortalized human epithelial cervical cells to benzo $[a]$ pyrene; Oncol. Rep. 6 (1999) 1371-1376.

652. Mitacek, E.J., K.D. Brunnemann, D. Hoffmann, T. Limsila, M. Suttajit, N. Martin, and L.S. Caplan: [Chemical Studies on Tobacco and Tobacco Smoke. CI.] Volatile nitrosamines and tobacco-specific nitrosamines in the smoke of Thai cigarettes: a risk factor for lung cancer and a suspected risk factor for liver cancer in Thailand; Carcinogenesis 20 (1999) 133-137.

653. Baker, F., S.R. Ainsworth, J.T. Dye, C. Crammer, M.J. Thun, D. Hoffmann, J.L. Repace, J.E. Henningfield, J. Slade, J. Pinney, T. Shanks, D.M. Burns, G.N. Connolly, and D.R. Shopland: Health risks associated with cigar smoking; JAMA 284 (2000) 735-740.

654. Brunnemann, K.D., J. Qi, and D. Hoffmann: Analytical comparison of two types of oral snuff; presented at the $54^{\text {th }}$ TSRC, Nashville, TN, 2000, No. 40.

655. Hecht, S.S. and D. Hoffmann: Re: Cigar smoking in men and risk of death from tobacco-related cancers; J. Natl. Cancer Inst. 92 (2000) 2040 [Comment on Shapiro et al.: J. Natl. Cancer Inst. 92 (2000) 333-337 and Boffetta et al.: J. Natl. Cancer Inst. 91 (1999) 697-701].

656. Hoffmann, D. and I. Hoffmann: Ernst L. Wynder, M.D., Dr. Sc. h.c. (Mult.), Dr. med. h.c. - 1922-1999. Ein Nachruf; Soz. Präventivmed. 45 (2000) 61-63.

657. Brunnemann, K.D., J. Qi, L.P. Bush, and D. Hoffmann: Alkaloid profile in oral moist snuff tobacco; presented at the $55^{\text {th }}$ TSRC, Greensboro, NC, 2001, No. 41.

658. Brunnemann, K.D., J. Qi, G.N. Connolly, and D. Hoffmann: Effects of storage on the levels of tobacco specific nitrosamines in oral moist snuff tobacco; presented at the $55^{\text {th }}$ TSRC, Greensboro, NC, 2001, No. 40.

659. Brunnemann, K.D, J. Qi, and D. Hoffmann: Aging of Oral Moist Snuff and the Yields of Tobacco-Specific N-Nitrosamines (TSNA); Progress Report, prepared for the Massachusetts Tobacco Control Program, Department of Public Health, Boston, MA, American Health Foundation, Valhalla, NY, 2001.

660. Hoffmann, D. and I. Hoffmann: The Changing Cigarette. Chemical studies and bioassays; in: Risks Associated with Smoking Cigarettes with Low-Machine-Measured Yields of Tar and Nicotine. Smoking and Tobacco Control Monogr. 13, NCI, Bethesda, MD, 2001, pp. 159-191.

661. Hoffmann, D., I. Hoffmann, and K. El-Bayoumy: The less harmful cigarette: a controversial issue. A tribute to Ernst L. Wynder; Chem. Res. Toxicol. 14 (2001) 767-790.

662. Brunnemann, K.D., J. Qi, and D. Hoffmann: Chemical profile of two types of oral snuff tobacco; Food Chem. Toxicol. 40 (2002) 1699-1703.

663. Prokopczyk, B., D. Hoffmann, M. Bologna, A.J. Cunningham, N. Trushin, S. Akerkar, T. Boyiri, S. Amin, D. Desai, S. Colosimo, B. Pittman, G. Leder, M. Ramadani, D. HenneBruns, H.G. Beger, and K. El-Bayoumy: Identification of tobacco-derived compounds in human pancreatic juice; Chem. Res. Toxicol. 15 (2002) 677-685.

664. Brunnemann, K.D. J. Qi, and D. Hoffmann: Extraction of nicotine and TSNA from moist snuff by snuff dippers; presented at the $57^{\text {th }}$ TSRC, Norfolk, VA, 2003, No. 20.

665. Melikian, A.A., J. Hosey, J. Zhang, S. Colosimo, D. Hoffmann, M. Varga, J.H. Jaffe, and W.B. Barr: Reduction of urinary metabolites of tobacco carcinogens in smokers who switched from conventional light cigarettes to a new cigarette with low levels of tobacco-specific nitrosamines and a modified filter tip; in: Proc. Am. Assoc. Cancer Res., 2003, No. 6414.

666. Brunnemann, K.D., J. Qi, and D. Hoffmann: Levels of TSNA in oral moist snuff in the past 30 years and today; presented on the $58^{\text {th }}$ TSRC, Winston-Salem, NC, 2004, No. 38.

667. El-Bayoumy, K., J.E. Muscat, and D. Hoffmann: Nutrition and tobacco-related cancer; in: Nutritional Oncology. $\left(2^{\text {nd }}\right.$ Edition); edited by G.I. Blackburn et al., Academic Press, San Diego, CA, 2006, pp. 199-218.

668. Trushin, N., G. Leder, K. El-Bayoumy, D. Hoffmann, H.G. Beger, D. Henne-Bruns, M. Ramadani, B. Prokopczyk: The tobacco carcinogen NNK is stereoselectively reduced by human pancreatic microsomes and cytosols; Langenbecks Arch. Surg. 393 (2008) 571-579.

669. Melikian, A.A. and D. Hoffmann: Smokeless tobacco: a gateway to smoking or a way away from smoking; presented at the Symposium for Aerosol Dynamics \& Health, 2008, Cardiff University School of Biosciences, Wales, UK, Biomarkers, 14 Suppl. 1 (2009) 85-89.

670. Schwartz, J.L, K.D. Brunnemann, A.J. Adami, S. Panda, S.C. Gordon, D. Hoffmann, G.R. Adami: Brand specific responses to smokeless tobacco in a rat lip canal model. J. Oral Pathol. Med. 39 (2010) 453-459. 